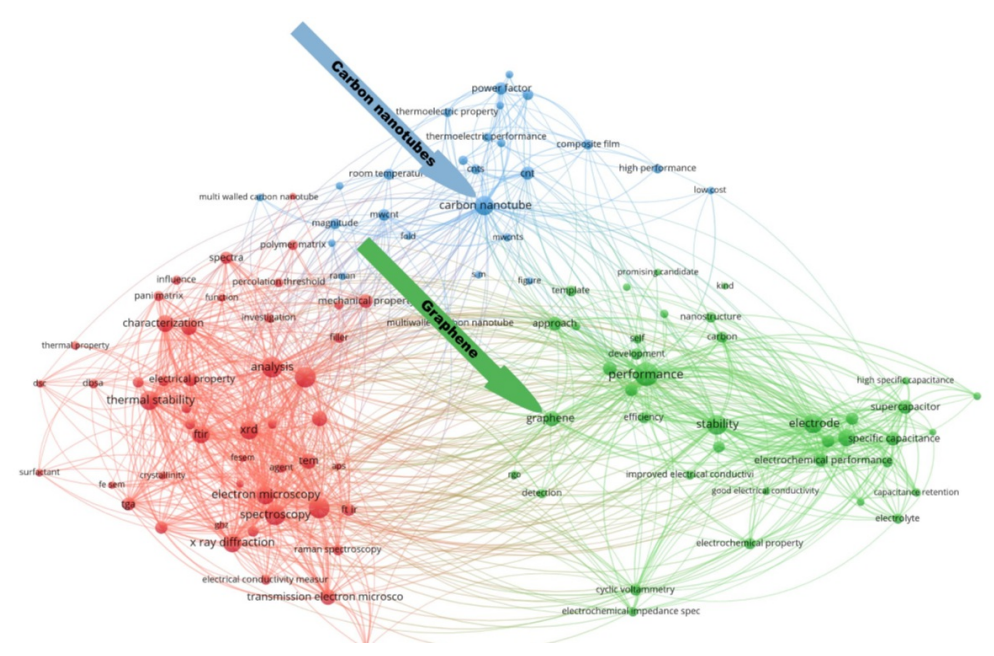

\title{
Can nanoparticles improve polyaniline electrical conductivity?
}

Fernando Gomes de Souza Jr ${ }^{1}$, Thaís Nogueira Barradas, Vinicius de Freitas Caetano, Angela Becerra Lovera $^{1}$

1 Universidade Federal do Rio de Janeiro

Funding: This work was supported by Conselho Nacional de Desenvolvimento Científico e Tecnológico (CNPq-304500/2019-4), Coordenação de Aperfeiçoamento de Pessoal de Nível Superior (CAPES - Finance Code 001) and Fundação Carlos Chagas Filho de Amparo à Pesquisa do Estado do Rio de Janeiro (FAPERJ - CNE2021).

Potential competing interests: The author(s) declared that no potential competing interests exist.

\section{Abstract}

Polyaniline is a conductive polymer that attracts the attention of many researchers around the world. The history of this polymer begins in 1862 when Letheby first reported this material. Since then, a myriad of studies has been conducted on this material, and new works continue to investigate the potential of this material. Polyaniline has been improved with the help of Nanotechnology. The use of nanofillers has been seen as a quick and economical way to modify materials, driving innovations based on new physical and chemical properties from the conductive polymer materials and nanoparticles joining. Several works address the use of different nanoparticles, which leads to the practical impossibility of sifting through all this information. Thus, this work proposes to systematically collect data in the literature and investigate which nanoparticles can increase the electrical conductivity of Polyaniline (PAni). The results obtained demonstrate that among the possible nanofillers, graphene and carbon nanotubes have great prominence. Furthermore, the results of the meta-analysis prove that PAni's conductivity increases when this polymer is modified with the aforementioned nanofillers. This work was developed using VOSViewer, a classification and grouping tool, and Jamovi, a new 3rd 
generation statistical tool used here for the meta-analysis calculation.

\section{INTRODUCTION}

Since polyaniline was reported by Letheby in 1862, a profusion of work has been developed on this material (1). Polyaniline (PAni) is a conductive polymer from the flexible polymer family, which has high electrical conductivity (2-13). Among conductive polymers, PAni is unique because of its easiness of synthesis (14-25). Besides, Professor MacDiarmid et al. (26) proved the PAni emeraldine base can be converted from an insulator to a metal-like material by treatment with aqueous $\mathrm{HCl}$, by forming the emeraldine-hydrochloride salt. Such transformation involves non-redox doping, in which a polaron conduction band, with most of the positive charge residing on the nitrogen atoms, is responsible for the electrical conductivity. PAni's doping process produces a nice color range from blue to green, which is useful for developing electrochromic devices, which is further favored by its good environmental stability (27-39). PAni has been one of the most studied polymers for the past 20 years.

Our research group has studied PAni dozens of times. Our first publication on PAni dates back to 2005 when we introduced a methodology for studying the dependence of electrical resistivity with pressure in conducting composites (40). Then, we studied several subjects regarding PAni, such as polymerization in the presence of carbon black (41), DBSA (42), cardanol bio-resin (43), cardanol-furfural bio-resin (44), DMIT (45), polyamide-6,6 (35), SBS $(46,47)$, nitrile rubber (48), EVA-NBR (49), poly(lactic acid) (50), curaua fibers (51), coconut fibers $(52,53)$, coir fibers (54), mango fibers (55), cotton fabrics $(56)$ as well as the influence of plasticizers $(57,58)$, magnetite $(59,60)$ and maghemite $(61,62)$. Next, the characterization of these materials by electrical surface colorimetry (63), resistivity (64), WAXS $(65,66)$, UV-Vis (67), XPS (68), NIR (69), and SAXS (70-73), were studied. Finally, a paper named "Polyaniline: Trends and perspectives from text-mining analysis" (74) was published in the Brazilian Journal of Experimental Design, Data Analysis, and Inferential Statistics. Thus, as evidenced by this set of studies, our research group has a relevant background in this subject, always looking for new ways to improve this polymer.

PAni is a typical conductive polymer, resulting from the oxidative polymerization of aniline, whose conductivity can be affected by the degree of doping, the type of dopant, the morphology, and the degree of crystallization (4). PAni has attracted attention in recent decades due to its characteristics such as low cost, high conductivity, and good resistance to the environment (18). Besides, PAni has special electronic properties, which can be reversibly controlled by the material's protonation/deprotonation processes (5). In addition, PAni has great potential for high-end applications, such as electrodes (18, 28, 38, 75-83), batteries (15, 84-93), microelectronics (94-102), electrochromic materials used in displays (103-110), sensors (22,111-118), and electromagnetic shielding (119-127). Despite its excellent properties, several studies have been carried out in an attempt to improve the properties of PAni. Among all of the documents about PAni listed in Scopus database $(n=30,788)$, almost $75 \%$ of them $(23,066)$ involved polyaniline and "nano". Therefore, the use of nanofillers is a quick and economical way to modify materials, driving innovations based on new physical and chemical properties from the conductive polymer materials and 
nanoparticles joining.

From a specific point of view, such as when studying a well-defined nanofiller-matrix system, synthetic issues must be considered for improvements in electrical properties. Besides that, it is crucial to understand which superficial modifications are necessary for achieving the desired improvement (127). However, the premise of this study was to proceed with a broad search on which nanoparticles could increase the conductivity of systems based on polyaniline.

Thus, the effect of the quantity in different nanofillers on the conductivity of the polyaniline matrix was studied. As the conductivity studies were conducted differently by their respective authors, the primary efforts were to analyze the slope and correlation between conductivity and the amount of different nanofillers. This procedure allowed for inferring that, among several possibilities, specific nanofillers, such as carbon nanotubes and graphene, are more exploited, aiming to increase the matrix conductivity. Furthermore, the meta-analysis results prove that PAni conductivity increases when this polymer is modified using the nanofillers mentioned earlier.

Of course, other nanofillers with the potential to increase conductivity may have escaped this study, but until new evidence emerges, carbon nanotubes and graphene should be the two preferred nanofillers for studies that seek to increase the conductivity of polyaniline.

\section{METHODS}

All the steps of this study were derived from a question: "Could nanoparticles improve polyaniline electrical conductivity or electrical resistivity?"

\subsection{Article search}

Research articles containing the term "polyaniline" in the title, keyword and abstract were collected using the Scopus database. The used key was TITLE-ABS-KEY ( polyaniline ). The number of papers published per year was plotted using QtiPlot Software. Articles with publication year of 2021 and 2022 were excluded, as the final number of articles is not consolidated yet. The date of the retrieval was $2^{\text {nd }}$ July, 2021 . Then, a second search key, more complex than the first, was used to refine the number of documents retrieved. In its complete form, the second search key was written as: TITLE-ABS-KEY ( nano* AND polyaniline AND improv* AND "electrical conductiv*" OR "electrical resistivit*" ) AND ( LIMIT-TO ( DOCTYPE , "ar")). Here, there was no limitation of the researched years. The RIS file containing these data is available at https://github.com/ftir-mc/Nanoparticles-improving-Pani-conductivity.git.

\subsection{Scientific scenarios evaluation with VOSviewer}

The bibliographical information for the documents containing abstract, author keyword and index 
keywords were exported as a RIS document and imported by VOSviewer (version 1.6.10) software (128). Different trending topics and themes were identified from the Titles and Abstracts. Then, the search was refined again. In its complete form, the third search key was written as: TITLE-ABS-KEY ( nano* AND polyaniline AND improv* AND "electrical conductiv*" OR "electrical resistivit*" AND graphene OR "carbon nanotub*") AND ( LIMIT-TO ( DOCTYPE , "ar " ) ). Once more, there was no limitation of the researched years.

\subsection{Data Extraction}

The articles were analyzed according the following criteria: nanofillers concentration in PAni, number of replicates, and standard deviation. Based on the inclusion criteria, information from all eligible publications were extracted. The following information were included in each study: name of first author, year of publication, filler (CNT or graphene), number of replicates, and the correlation between the electrical conductivity or electrical resistivity versus the percentual amount of nanofiller. When the document did not present the data tables, data was extracted from plots curves. Engauge Digitizer 3.0 (by Mark Mitchell) software was used to extract data from these figures. From data extracted, the $95 \%$ confidence intervals (CI95\%) were calculated.

\subsection{Statistical Analysis and Meta-analysis}

As several electrical measurement techniques were performed, the effect of nanofillers on the electrical conductivity of materials was evaluated by correlating the conductivity data and the mass quantity of the nanofiller in the material. The Jamovi (version 1.6.23.0) module MAJOR (129) was used to obtain Metaanalysis and Forest plot. The analysis was carried out using the Fisher r-to-z transformed correlation coefficient as the outcome measure. A random-effects model was fitted to the data. The amount of heterogeneity (i.e., $\operatorname{tau}^{2}$ ), was estimated using the restricted maximum-likelihood estimator (130). In addition to the estimate of $\operatorname{tau}^{2}$, the Q-test for heterogeneity (131) and the $\mathrm{I}^{2}$ statistic are reported. In case any amount of heterogeneity is detected (i.e., $\operatorname{tau}^{2}>0$, regardless of the results of the Q-test), a prediction interval for the true outcomes is also provided. Studentized residuals and Cook's distances are used to examine whether studies may be outliers and/or influential in the context of the model. Studies with a studentized residual larger than the $100 \times(1-0.05 /(2 \times k))$ th percentile of a standard normal distribution are considered potential outliers (i.e., using a Bonferroni correction with two-sided alpha $=0.05$ for $\mathrm{k}$ studies included in the meta-analysis). Studies with a Cook's distance larger than the median plus six times the interquartile range of the Cook's distances are considered to be influential. The rank correlation test and the regression test, using the standard error of the observed outcomes as predictor, are used to check for funnel plot asymmetry. 


\section{RESULTS}

From the Scopus database, 29584 documents were collected between 1969 and 2022. All the conference papers $(3,028)$, reviews (533), book chapters (252), and conference reviews (188) were excluded from the search. Thus, the documents were restricted to articles, remaining 25,396 titles. The number of documents published per year is shown in Figure 1.

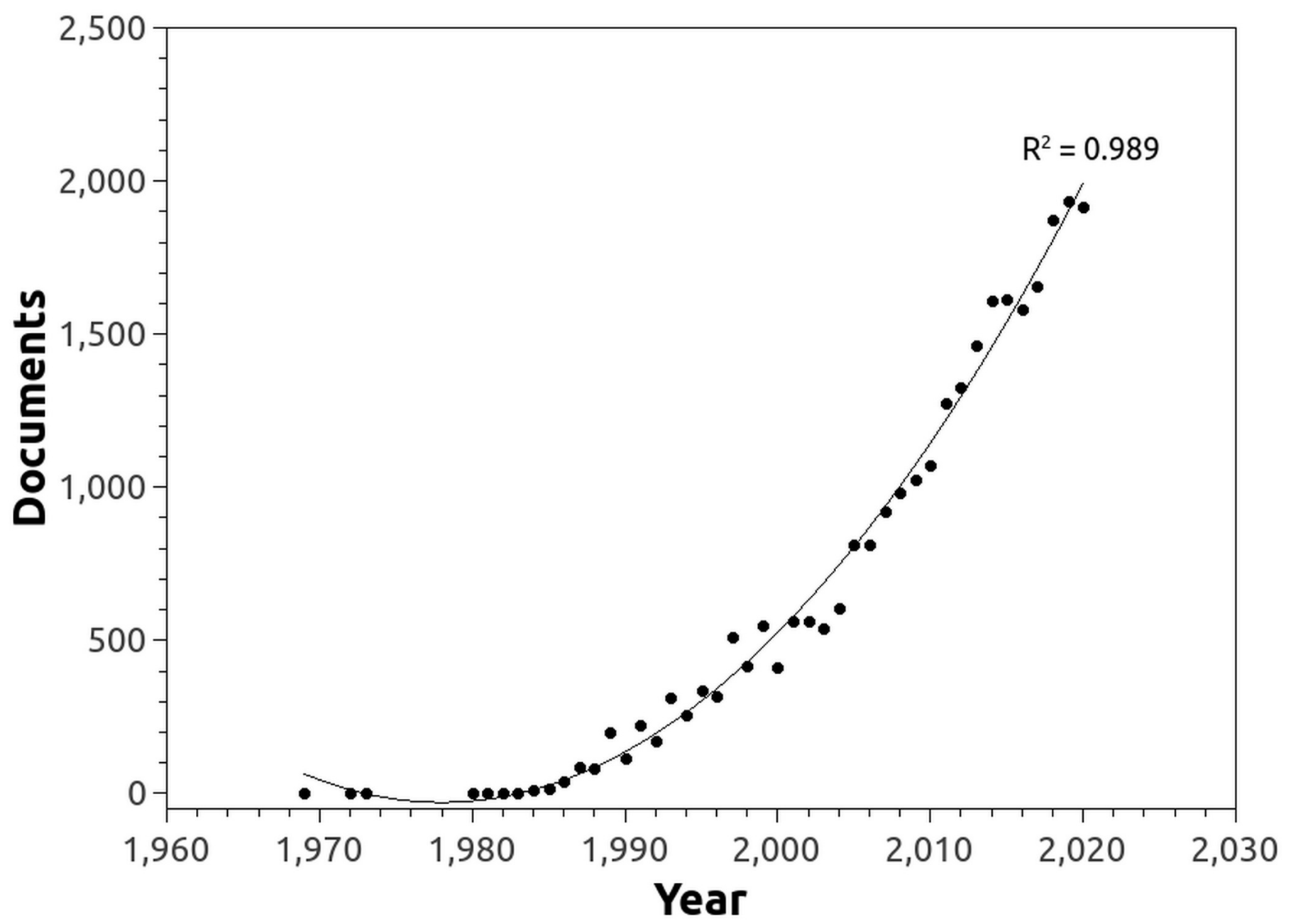

Figure 1 - Number of documents published per year using the key TITLE-ABS-KEY (polyaniline).

The data in Figure 1 follow a polynomial of order 2 . The coefficient of determination $\left(R^{2}\right)$ found was equal to 0.989. The model and the associated $R^{2}$ numerically demonstrate that interest in the PAni topic is 
accelerating since the 1980s. With the advent of nanotechnology, it is evident that these numbers will continue to grow over the next years.

Then, focusing on the key question of this research, 392 documents were found using the search key TITLE-ABS-KEY ( nano* AND polyaniline AND improv* AND "electrical conductiv*" OR "electrical resistivit*" ) AND ( LIMIT-TO ( DOCTYPE, "ar")). The titles and abstracts of these documents were saved in RIS format and analyzed using VOSviewer software. The obtained results are shown in Figure 2. Besides, the *MAP.txt and *NET.txt files generated by VOSviewer are available at https://github.com/ftir-mc/Nanoparticlesimproving-PAni-conductivity.git. 

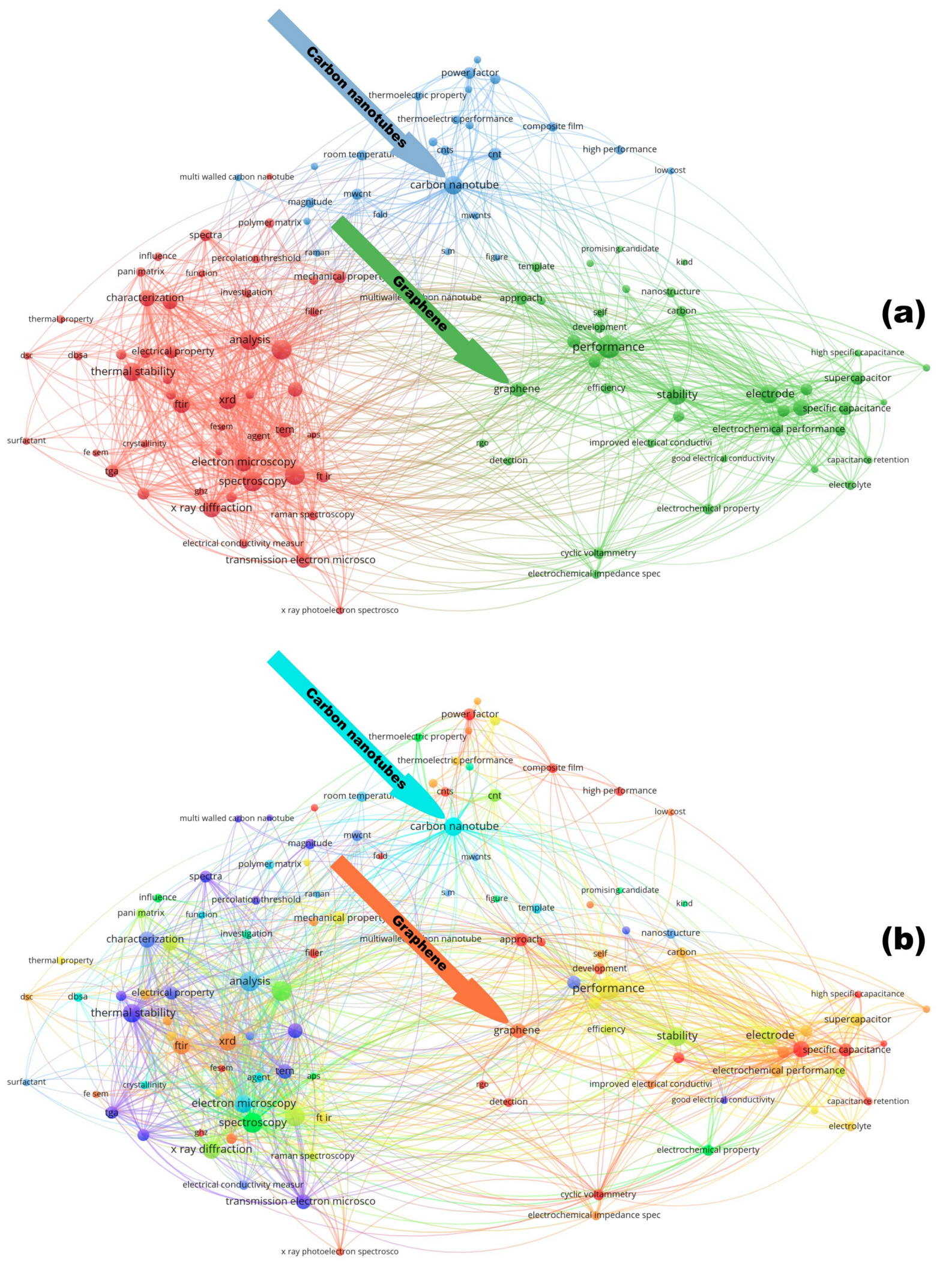

Figure 2 - VOSviewer network (a) and overlay visualizations (b) from the key TITLE-ABS-KEY (nano* AND polyaniline AND improv* AND "electrical conductiv*" OR "electrical resistivit*") AND ( LIMIT-TO ( DOCTYPE , "ar")). 
Figure 2 (a) shows the existence of three main clusters. The first one, in red, is dominated by several nodes related to the characterization techniques used by the authors in their studies. The second cluster, in blue, is dominated by the "carbon nanotube" node, a key constituent for the production of nano-modified materials based on PAni. Finally, the third cluster, in green, is dominated by the performance, stability, and electrode nodes. Afterward, the most important material node is the "graphene", showing that this material is another relevant nanofiller in the context of improving the electrical properties of PAni. The comparison between the strengths of the terms CNT and graphene was calculated based on the "Total link strength" values recorded in the *MAP.txt file. The calculation allows inferring that graphene corresponds to $68.3 \%$ of the relative strength of the CNTs in the references analyzed. Furthermore, Figure 2 (b) allows determining that the year of maximum interest for the terms carbon nanotube (2015.65) and graphene (2016.89) nanofillers differs by about 1.24 years. So, they are contemporary themes.

Thus, two new keywords, "carbon nanotubes" and "graphene", gained relevance. So these two new words were added to the search key (TITLE-ABS-KEY ( nano* AND polyaniline AND improv* AND "electrical conductiv*" OR "electrical resistivit*" AND graphene OR "carbon nanotub*") AND ( LIMIT-TO ( DOCTYPE , "ar " ) )), in a new refinement, which returned 177 documents (132-308).

All of these 177 documents were downloaded and their data were scratched looking for statistically relevant information for constructing the analysis here proposed. Table 1 shows the $1^{\text {st }}$ author of the study and the year of publication, the used nanofiller as well as the number of experimental conditions tested, the total number of replicates, and the Adjusted Correlation (adjR).

From the 177 selected documents, 15 presented useful data for the proposed meta-analysis. However, among the documents evaluated, some had more than one useful case. So, a total of $k=20$ studies were included in the analysis. The observed Fisher r-to-z transformed correlation coefficients ranged from 0.3713 to 3.1320 , with the majority of estimates being positive ( $100 \%)$. The estimated average Fisher r-to$z$ transformed correlation coefficient based on the random-effects model was û $=1.6441$ (95\% Cl: 1.3285 to 1.9596). Therefore, the average outcome differed significantly from zero ( $z=10.2119, p<0.0001)$. According to the Q-test, the true outcomes appear to be heterogeneous $(\mathrm{Q}(19)=165.5133, \mathrm{p}<0.0001$, $\operatorname{tau}^{2}=0.4428, I^{2}=86.1258 \%$ ). A 95\% prediction interval for the true outcomes is given by 0.3022 to 2.9859. Hence, even though there may be some heterogeneity, the true outcomes of the studies are generally in the same direction as the estimated average outcome. An examination of the studentized residuals revealed that none of the studies had a value larger than \pm 3.0233 and hence there was no indication of outliers in the context of this model. According to the Cook's distances, none of the studies could be considered to be overly influential. Neither the rank correlation nor the regression test indicated any funnel plot asymmetry ( $p=0.7584$ and $p=0.3707$, respectively). 
Table 1 - Statistically relevant data scratched from selected documents

\begin{tabular}{|c|c|c|c|c|c|}
\hline Authors & Year & Filler & Experiments & Total replicates & adjR \\
\hline Tung et al. (258) & 2011 & Graphene & 5 & 15 & 0.9880 \\
\hline Abadad et al. (218) & 2013 & Graphene & 11 & 33 & 0.9962 \\
\hline Liu \& Yu. (303) & 2014 & CNT & 5 & 15 & 0.9403 \\
\hline Wang et al. (274) & 2015 & DWCNT & 4 & 12 & 0.9592 \\
\hline Wang et al. (274) & 2015 & DWCNT & 6 & 18 & 0.9302 \\
\hline Wang et al. (178) & 2016 & CNT & 8 & 24 & 0.9732 \\
\hline Yazdi \& Motlagh. (295) & 2017 & Graphene & 5 & 15 & 0.5220 \\
\hline Mao et al. (146) & 2018 & CNT & 5 & 15 & 0.7332 \\
\hline Li et al. (228) & 2018 & CNT & 8 & 24 & 0.5138 \\
\hline Kumar et al. (270) & 2018 & MWCNT & 5 & 15 & 0.8398 \\
\hline Pathak et al. (220) & 2019 & Graphene & 6 & 18 & 0.7614 \\
\hline Li et al. (236) & 2019 & CNT & 5 & 15 & 0.3551 \\
\hline Zhang et al. (260) & 2020 & Graphene & 5 & 15 & 0.9503 \\
\hline Amirabad et al. (264) & 2020 & Graphene & 5 & 15 & 0.9643 \\
\hline Feng et al. (197) & 2021 & CNT & 5 & 15 & 0.9338 \\
\hline Feng et al. (197) & 2021 & CNT & 5 & 15 & 0.9812 \\
\hline Cho et al. (245) & 2021 & SWCNT & 5 & 15 & 0.9233 \\
\hline Cho et al. (245) & 2021 & DWCNT & 5 & 15 & 0.9785 \\
\hline Cho et al. (245) & 2021 & MWCNT & 5 & 15 & 0.9236 \\
\hline Cho et al. (245) & 2021 & Graphene & 6 & 18 & 0.9241 \\
\hline
\end{tabular}

Funnel plot is shown in Figure 3. 


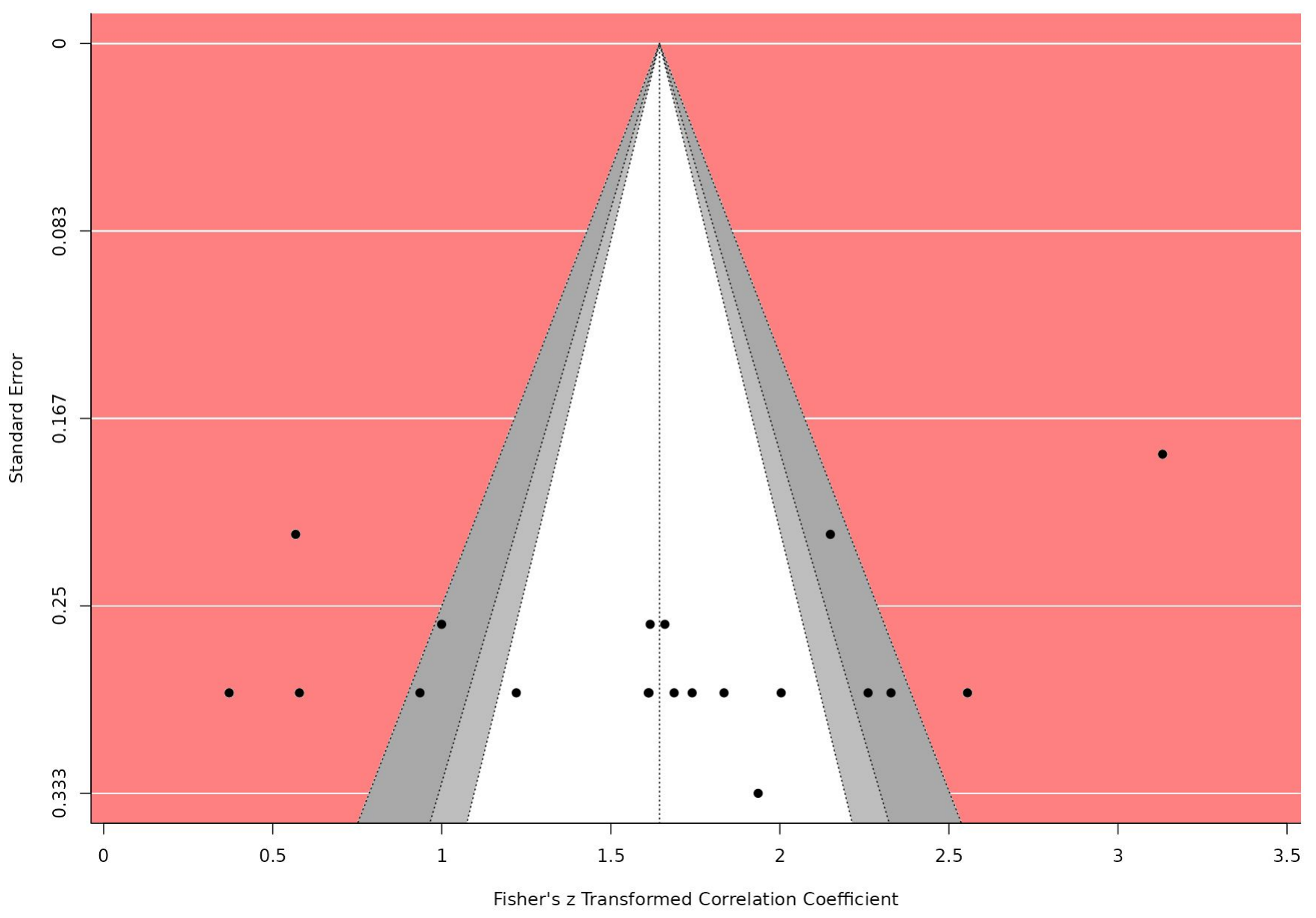

Figure 3 - Funnel plot for the selected studies.

Fisher's transformation is commonly used to eliminate a possible bias in the untransformed correlation coefficient (309). As the population value of correlation becomes further from zero, the sampling distribution of correlation coefficients becomes skewed, and Fisher's transformation normalizes this sampling distribution. Empirical evidence suggests that transforming the correlation coefficient can be beneficial (310). Mainly because many meta-analytic methods assume that the sampling distribution of observed results is normal. When the correlation in a particular study is far from zero, and the sample size is small, then the gross sample distribution of the correlation becomes skewed, no longer being closely approximated by a normal distribution. In this context, Fisher's r-to-z transformation is an effective normalization transformation, which makes the statistical analysis of correlations independent of unknown quantities (311).

On Fisher's transformation of the correlation coefficient, the actual effect is 1.64. Most studies are in the Standard Error region between 0.25 and 0.33 , that is, at the base of the Funnel Plot. As described in line 287 of Jamovi MAJOR Module source code (312), the data are distributed among regions comprising $90 \%$ 
(white), 95\% (gray), 99\% (dark gray), and the rest are beyond 99\% (red) probability.

Forest plots are a key-graphical method used in meta-analysis. The forest plot is the graphical representation resulting from quantitative systematic reviews. This representation is designed to compare the effects of treatments in quantitative studies. The term "forest" comes from the idea that the graph resembles a forest of lines. Originally the forest plot was designed to compare randomized clinical trials that addressed a common theme. Currently, however, this representation is quite prevalent in observational studies, to visually present the mathematical significance of the joint conclusions of several works analyzed as a block (313-315).

The Forest Plot, shown in Figure 4, lists all selected studies. The relevance of the studies is presented in percentage form. All studies had similar percentage relevance. The effects and their $95 \%$ probability confidence limits are shown to the right side of the percent relevance.

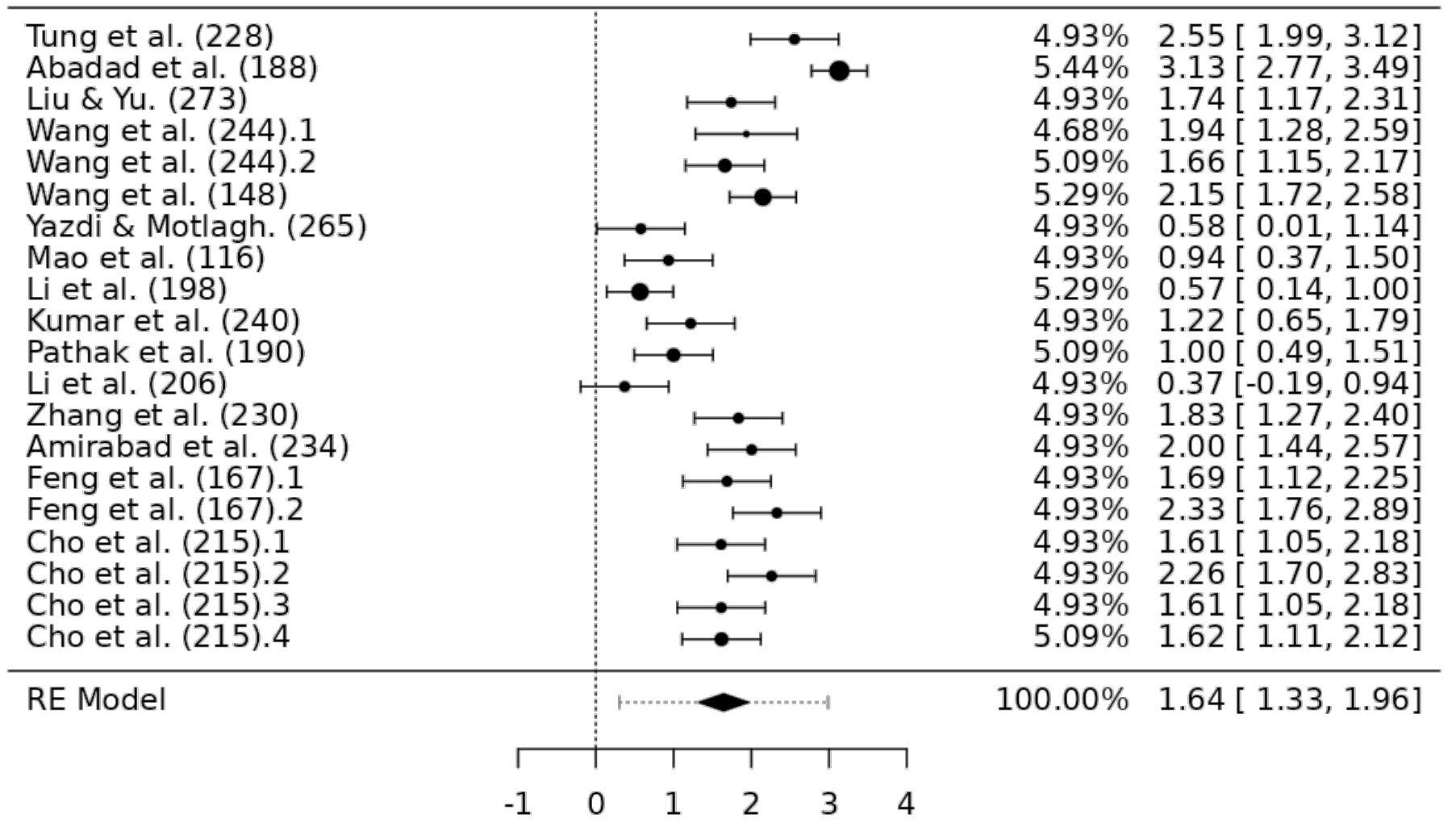

Figure 4 - Forest plot for the selected studies.

The modeled effect is equal to 1.64, with the lower bound equal to 1.33 and the upper bound equal to 1.96. Thus, the modeled effect is positive and nonzero. So, the meta-analysis proved that the nanofillers in this study increase the conductivity of PAni. Therefore, graphene and CNT should be prioritized in future works involving PAni until new evidence suggests the use of different nanofillers. 


\section{CONCLUSIONS}

This study conducted a systematic search for several scientific pieces of research that would allow us to determine whether nanofillers can improve the electrical conductivity of PAni. Thousands of works were analyzed using VOSviewer, which concluded that graphene and carbon nanotubes are the two most studied nanofillers. Thus, hundreds of works involving PAni's modification via these nanofillers were identified from these papers. From them, fifteen presented extractable and helpful information to the meta-analysis. Meta-analysis proved that these nanofillers could effectively increase the conductivity of PAni. Therefore, graphene and CNT should be prioritized in future works involving PAni until new evidence suggests using different nanofillers.

\section{Acknowledgments}

This work was supported by Conselho Nacional de Desenvolvimento Científico e Tecnológico (CNPq304500/2019-4), Coordenação de Aperfeiçoamento de Pessoal de Nível Superior (CAPES - Finance Code 001) and Fundação Carlos Chagas Filho de Amparo à Pesquisa do Estado do Rio de Janeiro (FAPERJ CNE2021).

\section{Sample CRediT author statement}

Fernando G. de Souza Junior: Conceptualization, Methodology, Data analysis, and Writing-Original draft preparation and Supervision. Thaís Nogueira Barradas: Conceptualization, Methodology, Data analysis and Revision. Vinicius Freitas Caetano: Methodology, Data analysis and Revision. Angela Becerra: Methodology, Data analysis and Revision.

\section{Conflict of interest: None}

\section{REFERENCES}

1. LETHEBY, H. On the production of a blue substance by the electrolysis of sulphate of aniline. Journal of the Chemical Society. v. 15, n. 0, p. 161-163. 1862. DOI 10.1039/JS8621500161. 0261

2. GONÇALVES, Raiane Valenti, ZANINI, Mara Lise, MALMONGE, José Antonio, BONNAUD, Leila and BASSO, Nara Regina de Souza. Cashew nut shell liquid, a valuable raw material for generating semiconductive polyaniline nanofibers. Polímeros. v. 28, n. 1, p. 61-68. 2018. DOI 10.1590/0104-1428.01417.

3. BIBI, Ariba and SHAKOOR, Abdul. Charge transport mechanism in dodecylbenzenesulfonic acid doped polyaniline/carbon black composites. Polymers and Polymer Composites. P. 09673911211040376. 2021. DOI 10.1177/09673911211040376. 
4. LIU, Wangcheng, ZHANG, Jinwen and LIU, Hang. Conductive Bicomponent Fibers Containing Polyaniline Produced via Side-by-Side Electrospinning. Polymers. v. 11, n. 6, p. 954. 2019. DOI 10.3390/polym11060954.

5. SAPURINA, Irina, TENKOVTSEV, Andrey V and STEJSKAL, Jaroslav. Conjugated polyaniline as a result of the benzidine rearrangement. Polymer International. v. 64, n. 4, p. 453-465. 2015. DOI 10.1002/pi.4869.

6. ANDRIIANOVA, Anastasia N., ABYALILOVA, Aigul R., BIGLOVA, Yulia N. and MUSTAFIN, Akhat G. Effect of Cobalt Phthalocyanine on the Chemical Polymerization of Aniline. ChemistrySelect. v. 5, n. 19, p. 56215628. 2020. DOI 10.1002/slct.202001086.

7. MOHD YAZID, Mohammed Izzuddeen, OSMAN, Azlin Fazlina, GHANI, Supri Abdul, LENG, Teh Pei and MOHD DIN, Siti Hajar. Effects of polyaniline loading and naphthalene surface modifier on properties of conductive polyethylene oxide/polyvinyl chloride/polyaniline films. Journal of Vinyl and Additive Technology. P. n/a-n/a. DOI 10.1002/vnl.21629.

8. LEYVA EGURROLA, Saul, DEL CASTILLO CASTRO, Teresa, CASTILLO ORTEGA, María Mónica, ENCINAS, José Carmelo, HERRERA FRANCO, Pedro Jesús, BONILLA CRUZ, José and LARA CENICEROS, Tania E. Electrical, mechanical, and piezoresistive properties of carbon nanotube-polyaniline hybrid filled polydimethylsiloxane composites. Journal of Applied Polymer Science [online] . v. 134, n. 18. 2017. DOI 10.1002/app.44780. Available from: http://doi.wiley.com/10.1002/app.44780. Accessed 19 September 2017.

9. AMORIM, Daniel Roger Bezerra, BELLUCCI, Felipe Silva, JOB, Aldo Eloizo, GUIMARÃES, Iran da Silva and DA CUNHA, Helder Nunes. Electrical, structural and thermal properties of new conductive blends (PANICG) based on polyaniline and cashew gum for organic electronic. Journal of Thermal Analysis and Calorimetry [online]. 2018. DOI 10.1007/s10973-018-7778-6. Available from: https://doi.org/10.1007/s10973-018-7778-6. Accessed 29 October 2018. 10. GUO, Rui, WANG, Jiao, WANG, Haihua, FEI, Guiqiang, WANG, Caiyun, SUN, Liyu and WALLACE, Gordon G. Engineering the poly(vinyl alcohol)-polyaniline colloids for high-performance waterborne alkyd anticorrosion coating. Applied Surface Science [online]. 2019. DOI 10.1016/j.apsusc.2019.03.078. Available from: https://linkinghub.elsevier.com/retrieve/pii/S0169433219306981. Accessed 25 March 2019.

11. UNIVERSITI MALAYSIA PERLIS (UNIMAP), MALAYSIA, MOHD. YAZID, Mohammed Izzuddeen, A. GHANI, Supri, UNIVERSITI MALAYSIA PERLIS (UNIMAP), MALAYSIA, OSMAN, Azlin Fazlina, UNIVERSITI MALAYSIA PERLIS (UNIMAP), MALAYSIA, MOHD. DIN, Siti Hajar, and UNIVERSITI MALAYSIA PERLIS (UNIMAP), MALAYSIA. Enhancement of Electrical Conductivity and Tensile Properties of Conductive Poly(vinyl Chloride)/Poly(ethylene Oxide)/Polyaniline Conductive Composite Films: Effect of Polyaniline Loading and Ethylene Dimethacrylate. Journal of Physical Science. v. 29, n. 2, p. 1-12. 2018. DOI 10.21315/jps2018.29.2.1.

12. OGURTSOV, Nikolay A., NOSKOV, Yuriy V., BLIZNYUK, Valery N., ILYIN, Vladimir G., WOJKIEWICZ, Jean- 
Luc, FEDORENKO, Elena A. and PUD, Alexander A. Evolution and Interdependence of Structure and Properties of Nanocomposites of Multiwall Carbon Nanotubes with Polyaniline. The Journal of Physical Chemistry C. v. 120, n. 1, p. 230-242. 2016. DOI 10.1021/acs.jpcc.5b08524.

13. ATTIA, R M, YOUSIF, N M, HELAL, R H and ALI, N M. Fabricating electronic textile using nano MnO2/polyaniline composites for capacitor device. Journal of Industrial Textiles. P. 1528083719896765. 2019. DOI 10.1177/1528083719896765.

14. OGURTSOV, Nikolay A., MIKHAYLOV, Sergei D., CODDEVILLE, Patrice, WOJKIEWICZ, Jean-Luc, DUDARENKO, Galina V. and PUD, Alexander A. Influence of Dispersed Nanoparticles on the Kinetics of Formation and Molecular Mass of Polyaniline. The Journal of Physical Chemistry B [online]. 2016. DOI 10.1021/acs.jpcb.6b05944. Available from: http://pubs.acs.org/doi/abs/10.1021/acs.jpcb.6b05944. Accessed 19 September 2017.

15. MALEKI, Mahboubeh, TICHTER, Tim, EL-NAGAR, Gumaa A., LAUERMANN, Iver and ROTH, Christina. Hybrid Electrospun Nanofibers as Electrocatalyst for Vanadium Redox Flow Batteries: Theory and Experiment. ChemElectroChem [online]. v. n/a, n. n/a. DOI https://doi.org/10.1002/celc.202001380. Available from: https://chemistry-europe.onlinelibrary.wiley.com/doi/abs/10.1002/celc.202001380. Accessed 26 December 2020.

16. WANG, Junling, ZHAN, Jing, MU, Xiaowei, JIN, Xin, CHU, Fukai, KAN, Yongchun and XING, Weiyi. Manganese phytate dotted polyaniline shell enwrapped carbon nanotube: Towards the reinforcements in fire safety and mechanical property of polymer. Journal of Colloid and Interface Science . v. 529, p. 345-356. 2018. DOI https://doi.org/10.1016/j.jcis.2018.06.038.

17. ALMAZÁN, Claudia María De León, CHÁVEZ-CINCO, María Yolanda, PÁRAMO-GARCíA, Ulises, MENDOZAMARTíNEZ, Ana María, ESTRADA-MORENO, Iván Alziri and RIVERA-ARMENTA, José Luis. PANI/SBR composites as anticorrosive coatings for carbon steel I. Chemical, morphological and superficial characterization. Polymer Bulletin. v. 73, n. 6, p. 1595-1605. 2016. DOI 10.1007/s00289-015-1565-3. 18. CHANG, Ziyang, LI, Shuangyang, SUN, Lijian, DING, Chunyue, AN, Xianhui and QIAN, Xueren. Paperbased electrode comprising zirconium phenylphosphonate modified cellulose fibers and porous polyaniline. Cellulose [online]. 2019. DOI 10.1007/s10570-019-02523-9. Available from:

https://doi.org/10.1007/s10570-019-02523-9. Accessed 25 June 2019.

19. T. V, Jinitha, P, Safna Hussan K., N, Subair, V, Shaniba, K. BALAN, Aparna and E, Purushothaman. Polyaniline modified lignocellulosic fibers from sago seed shell powder for electrochemical devices. RSC Advances. v. 8, n. 60, p. 34388-34396. 2018. DOI 10.1039/C8RA05774E.

20. SU, Na. Polyaniline-Doped Spherical Polyelectrolyte Brush Nanocomposites with Enhanced Electrical Conductivity, Thermal Stability, and Solubility Property. Polymers. v. 7, n. 9, p. 1599-1616. 2015. DOI 10.3390/polym7091473.

21. THORNTON, Breland T. E., HARRISON, Andrew, PHAM, Amanda L., CASTANO, Carlos E. and TANG, Christina. Polyaniline-Functionalized Nanofibers for Colorimetric Detection of HCl Vapor. ACS Omega. v. 3, n. 3, p. 3587-3591. 2018. DOI 10.1021/acsomega.8b00054. 
22. IRFAN, Muhammad Shafiq, GILL, Yasir Qayyum, MALIK, Sanaullah, NAEEM, Muhammad Tayyab, SAEED, Farhan and HASHMI, Motahira. Polyaniline-NBR Blends by in situ Polymerization: Application as Stretchable Strain Sensors. Smart Materials and Structures [online]. 2019. DOI 10.1088/1361-665X/ab1df3. Available from: http://iopscience.iop.org/10.1088/1361-665X/ab1df3. Accessed 7 May 2019.

23. ALVES, Fernando Henrique de Oliveira, ARAÚJO, Olacir Alves, DE OLIVEIRA, Aderbal Carlos and GARG, Vijayendra Kumar. Preparation and characterization of PAni(CA)/Magnetic iron oxide hybrids and evaluation in adsorption/photodegradation of blue methylene dye. Surfaces and Interfaces. P. 100954. 2021. DOI 10.1016/j.surfin.2021.100954.

24. HONG, Jianhan, HAN, Xiao, SHI, Hanping, JIN, Lihua and YAO, Juming. Preparation of conductive silk fibroin yarns coated with polyaniline using an improved method based on in situ polymerization.

Synthetic Metals. v. 235, p. 89-96. 2018. DOI https://doi.org/10.1016/j.synthmet.2017.12.002.

25. MACDIARMID, A. G., CHIANG, J. C., RICHTER, A. F. and EPSTEIN, A. J. Polyaniline: a new concept in conducting polymers. Synthetic Metals. v. 18, n. 1, p. 285-290. 1987. DOI 10.1016/03796779(87)90893-9.

26. AL-JALLAD, Mazen and ATASSI, Yomen. Preparation of nonwoven mats of electrospun poly(lactic acid)/polyaniline blend nanofibers: A new approach. Journal of Applied Polymer Science. v. 133, n. 29, p. n/a-n/a. 2016. DOI 10.1002/app.43687.

27. HAN, Chunlei, YE, Yali, WANG, Guanwen, HONG, Wei and FENG, Chunhua. Selective electro-oxidation of phenol to benzoquinone/hydroquinone on polyaniline enhances capacitance and cycling stability of polyaniline electrodes. Chemical Engineering Journal. v. 347, p. 648-659. 2018. DOI https://doi.org/10.1016/j.cej.2018.04.109.

28. DE LEÓN-ALMAZÁN, Claudia María, ESTRADA-MORENO, Iván Alziri, OLMEDO-MARTínEZ, Jorge L. and RIVERA-ARMENTA, José Luis. Semiconducting elastomers based on polyaniline/clay nanocomposites and SEBS obtained by an alternative processing technique. Synthetic Metals. v. 268, p. 116460. 2020. DOI 10.1016/j.synthmet.2020.116460.

29. DIREKSILP, Chatrawee and SIRIVAT, Anuvat. Synthesis and Characterization of Hollow-Sphered Poly(Nmethyaniline) for Enhanced Electrical Conductivity Based on the Anionic Surfactant Templates and Doping. Polymers. v. 12, n. 5, p. 1023. 2020. DOI 10.3390/polym12051023.

30. KALOTRA, Shivani and MEHTA, Rajeev. Synthesis of polyaniline/clay nanocomposites by in situ polymerization and its application for the removal of Acid Green 25 dye from wastewater. Polymer Bulletin [online]. 2020. DOI 10.1007/s00289-020-03222-3. Available from:

https://doi.org/10.1007/s00289-020-03222-3. Accessed 12 May 2020.

31. PONTES, Ketly, SOARES, Bluma G., BARRA, Guilherme M. O. and LIVI, Sebastien. The Effect of Ionic Liquid on the Development of Polyaniline/Natural Fibers and Biodegradable Conductive Composites Based on Poly(Butylene Adipate-co-Terephthalate). Macromolecular Symposia. v. 380, n. 1, p. 1800101. 2018. DOI 10.1002/masy.201800101.

32. YAZID, M I M, GHANI, S A, OSMAN, A F, DIN, S H M and JIN, T S. The effect on poly (ethylene oxide) / 
poly (vinyl chloride) / polyaniline (PAni) films by ethylene dimethacrylate as surface modifier: electrical conductivity and characterization. Journal of Physics: Conference Series. v. 908, p. 012007. 2017. DOI 10.1088/1742-6596/908/1/012007.

33. GÜNEŞOĞLU, Cem, GÜNEŞOĞLU, Sinem, WEl, Suying and GUO, Zhanhu. The enhanced electrical conductivity of cotton fabrics via polymeric nanocomposites. Fibers and Polymers. v. 17, n. 3, p. 402407. 2016. DOI 10.1007/s12221-016-5751-1.

34. LOPES, Eluise S., DOMINGOS, Eloílson, NEVES, Rodrigo S., ROMÃO, Wanderson, SOUZA, Kátia R. de, VALASKI, R., ARCHANJO, Braulio S., SOUZA, Fernando G., SILVA, Alexander M., KUZNETSOV, Alexei and ARAUJO, Joyce R. The role of intermolecular interactions in polyaniline/polyamide-6,6 pressure-sensitive blends studied by DFT and 1H NMR. European Polymer Journal. v. 85, p. 588-604. 2016. DOI https://doi.org/10.1016/j.eurpolymj.2016.11.011.

35. SINGH, B. and DAS, B. The synthesis and study of structural, optical and electrical behaviours of tin oxide / polyaniline nanocomposites. Pramana. v. 93, n. 2, p. 32. 2019. DOI 10.1007/s12043-019-1794-3. 36. CAI, Meng, YAN, Han, LI, Yuting, LI, Wen, LI, Hao, FAN, Xiaoqiang and ZHU, Minhao. Ti3C2Tx/PANI composites with tunable conductivity towards anticorrosion application. Chemical Engineering Journal . v. 410, p. 128310. 2021. DOI 10.1016/j.cej.2020.128310.

37. ZHANG, Ying, TAO, Yulun, WANG, Kequan, ZHAO, Shuai, ZHU, Jinbo and CHENG, Hao. Two kinds of polyaniline fiber photo sensor with interdigital electrode and flexible hydrogel. Journal of Applied

Polymer Science. v. n/a, n. n/a, p. 50628. DOI https://doi.org/10.1002/app.50628.

38. YAZID, Mohammed Izzuddeen Bin Mohd, GHANI, Supri A, JIN, Tan Soo, OSMAN, Azlin Fazlina and DIN, Siti Hajar Mohd. Utilization of Polyaniline (PAni) as Conductive Filler on Poly (Ethylene Oxide) / Poly (Vinyl Chloride) Films: Effects of Naphthalene as Surface Modifier on Electrical Conductivity. Journal of Physics: Conference Series. v. 908, p. 012006. 2017. DOI 10.1088/1742-6596/908/1/012006.

39. SOUZA JR, F.G., MICHEL, Ricardo C. and SOARES, Bluma G. A methodology for studying the dependence of electrical resistivity with pressure in conducting composites. Polymer Testing. v. 24, n. 8, p. 9981004. 2005. DOI 10.1016/j.polymertesting.2005.08.001. 0000

40. SOUZA JR., F.G., SIRELLI, Lys, MICHEL, Ricardo C, SOARES, Bluma G and HERBST, Marcelo H. In situ polymerization of aniline in the presence of carbon black. Journal of Applied Polymer Science. v. 102, n. 1, p. 535-541. 2006. DOI 10.1002/app.24280. 0020

41. SOUZA JR., F.G., ANZAI, Thiago Koichi, MELO JR., Príamo Albuquerque, SOARES, Bluma G, NELE, Márcio and PINTO, José Carlos. Influence of reaction media on pressure sensitivity of polyanilines doped with DBSA. Journal of Applied Polymer Science. v. 107, n. 4, p. 2404-2413. 2008. DOI 10.1002/app.27290. 0000

42. SOUZA JR., F.G., RICHA, Priscila, DE SIERVO, Abner, OLIVEIRA, Geiza E, RODRIGUES, Cezar H. M, NELE, Márcio and PINTO, José Carlos. New in situ Blends of Polyaniline and Cardanol Bio-Resins.

Macromolecular Materials and Engineering. v. 293, n. 8, p. 675-683. 2008. DOI

10.1002/mame.200800077. 0003 
43. SOUZA JR, F.G., ORLANDO, Marcos T. D, MICHEL, Ricardo C, PINTO, José Carlos, COSME, Tainá and OLIVEIRA, Geiza E. Effect of pressure on the structure and electrical conductivity of cardanol-furfuralpolyaniline blends. Journal of Applied Polymer Science. v. 119, n. 5, p. 2666-2673. 2011. DOI 10.1002/app.32848. 0000

44. PICCIANI, Paulo H.S., SOUZA JR., F.G., COMERLATO, Nadia M. and SOARES, Bluma G. A novel material based on polyaniline doped with [Cs][In(dmit)2], (cesium) [bis(1,3-dithiole-2-thione-4,5-dithiolato)indium (III)]. Synthetic Metals. v. 157, n. 24, p. 1074-1079. 2007. DOI 10.1016/j.synthmet.2007.11.004. 0008 45. SOUZA JR., Fernando G., SOARES, Bluma G., SILVEIRA, Fabiola, RENUKAPPA, N.M. and SIDDARAMAIAH, Siddaramaiah. Dielectric Behavior of SBS/Polyaniline Thermally Processable Blends. Chemistry \& Chemical Technology. v. 12, n. 4, p. 441-446. 2018. DOI 10.23939/chcht12.04.441. 46. SOUZA JR., F.G., PINTO, José C. and SOARES, Bluma G. SBS/Pani · DBSA mixture plasticized with DOP and NCLS - Effect of the plasticizers on the probability density of volume resistivity measurements.

European Polymer Journal. v. 43, n. 5, p. 2007-2016. 2007. DOI 10.1016/j.eurpolymj.2007.02.037. 0000 47. SOARES, Bluma G., AMORIM, Gabriel S., SOUZA JR., F.G., OLIVEIRA, Marcia G. and SILVA, J.E. Pereira da. The in situ polymerization of aniline in nitrile rubber. Synthetic Metals. v. 156, n. 2-4, p. 91-98. 2006. DOI 10.1016/j.synthmet.2005.09.045. 0033

48. SOUZA JR., F.G., ALMEIDA, Maurício, SOARES, Bluma G. and CARLOS PINTO, José. Preparation of a semiconductive thermoplastic elastomer vulcanizate based on EVA and NBR blends with polyaniline. Polymer Testing. v. 26, n. 5, p. 692-697. 2007. DOI 10.1016/j.polymertesting.2007.04.008. 0000 49. PICCIANI, Paulo H. S, SOARES, Bluma G, MEDEIROS, Eliton S, SOUZA JR., F.G., WOOD, Delilah F, ORTS, William J and MATTOSO, Luiz H. C. Electrospinning of Polyaniline/Poly(Lactic Acid) Ultrathin Fibers: Process and Statistical Modeling using a Non Gaussian Approach. Macromolecular Theory and Simulations. v. 18, n. 9, p. 528-536. 2009. DOI 10.1002/mats.200900053. 0004 50. SOUZA JR, F.G., OliVeIRA, Geiza E, RODRIGUES, Cezar H. M, SOARES, Bluma G, NELE, Márcio and PINTO, José Carlos. Natural Brazilian Amazonic (Curauá) Fibers Modified with Polyaniline Nanoparticles. Macromolecular Materials and Engineering. v. 294, n. 8, p. 484-491. 2009. DOI 10.1002/mame.200900033. 0007

51. SOUZA JR, F.G., CARLOS PINTO, José, ALVES GARCIA, Flávia, DE OLIVEIRA, Geiza Esperandio, BRUNO TAVARES, Maria Inês, DA SILVA, Andréa Maria and DAHER PEREIRA, Emiliane. Modification of coconut fibers with polyaniline for manufacture of pressure-sensitive devices. Polymer Engineering \& Science. v. 54, n. 12, p. 2887-2895. 2014. DOI 10.1002/pen.23845.

52. SOUZA JR, F.G., PAIVA, Luciana O, MICHEL, Ricardo C and DE OLIVEIRA, Geiza E. Modificação da fibra de coco com polianilina e o seu uso como sensor de pressão. Polímeros. v. 21, n. 1, p. 39-46. 2011. DOI 10.1590/S0104-14282011005000016. 0000

53. FERREIRA, Saulo Rocha, DA SILVA, Andréa Maria, SOUZA JR, F.G., FILHO, Romildo Dias Toledo and DE ANDRADE SILVA, Flávio. Effect of Polyaniline and H2O2 Surface Modification on the Tensile Behavior and Chemical Properties of Coir Fibers. Journal of Biobased Materials and Bioenergy . v. 8, n. 6, p. 578- 
586. 2014. DOI 10.1166/jbmb.2014.1478.

54. SOUZA JR. F.G., ANDRÉA MARIA DA SILVA, DE OLIVEIRA, Geiza Esperandio, COSTA, Raphael Maria, FERNANDES, Edson Rodrigo and PEREIRA, Emiliane Daher. Conducting and magnetic mango fibers. Industrial Crops and Products. v. 68, p. 97-104. 2015. DOI 10.1016/j.indcrop.2014.09.032. 55. DE ALMEIDA, Thuanny Moraes, DA SILVEIRA MARANHÃO, Fabíola, DE CARVALHO, Fernanda Veloso, MIDDEA, Antonieta, DE ARAUJO, Joyce Rodrigues and DE SOUZA JÚNIOR, Fernando Gomes. H2S Sensing Material Based on Cotton Fabrics Modified with Polyaniline. Macromolecular Symposia. v. 381, n. 1, p. 1800111. 2018. DOI 10.1002/masy.201800111.

56. SOUZA, Fernando G., SOARES, Bluma G., SIDDARAMAIAH, BARRA, Guilherme M. O. and HERBST, Marcelo H. Influence of plasticizers (DOP and CNSL) on mechanical and electrical properties of SBS/polyaniline blends. Polymer. v. 47, n. 21, p. 7548-7553. 2006. DOI https://doi.org/10.1016/j.polymer.2006.08.026.

57. SOUZA JR, F.G., PINTO, José C., DE OLIVEIRA, Geiza E. and SOARES, Bluma G. Evaluation of electrical properties of SBS/Pani blends plasticized with DOP and CNSL using an empirical statistical model. Polymer Testing. v. 26, n. 6, p. 720-728. 2007. DOI 10.1016/j.polymertesting.2007.03.004. 0010 58. VELOSO DE CARVALHO, Fernanda, PAL, Kaushik, SOUZA JR, F. G., DIAS TOLEDO FILHO, Romildo, MORAES DE ALMEIDA, Thuanny, DAHER PEREIRA, Emiliane, THODE FILHO, Sérgio, GALAL ABOELKHEIR, Mostafa, CORRÊA COSTA, Vitor, RICARDO BARBOSA DE LIMA, Nathali and DA SILVEIRA MARANHÃO, Fabíola. Polyaniline and magnetite on curaua fibers for molecular interface improvement with a cement matrix. Journal of Molecular Structure. v. 1233, p. 130101. 2021. DOI 10.1016/j.molstruc.2021.130101.

59. ALMEIDA MORAES, Thuanny, FARRÔCO, Maria Julia, PONTES, Ketly, FONTES BITTENCOURT, Magda, GUENTER SOARES, Bluma and GOMES SOUZA, Fernando. An optical-magnetic Material as a toxic gas filter and sensing device. RSC Advances. v. 10, n. 39, p. 23233-23244. 2020. DOI 10.1039/D0RA00537A. 60. SOUZA JR., F.G., MARINS, Jéssica, PINTO, José, DE OLIVEIRA, Geiza, RODRIGUES, Cezar and LIMA, Luis. Magnetic field sensor based on a maghemite/polyaniline hybrid material. Journal of Materials Science. v. 45, n. 18, p. 5012-5021. 2010. DOI 10.1007/s10853-010-4321-y. 0005

61. COSTA, Renata Cerruti da and SOUZA JR., F.G. Preparo de nanocompósitos de maghemita e polianilina assistido por ultrassom. Polímeros. v. 24, n. 2, p. 243-249. 2014. DOI 10.4322/polimeros.2014.035. 62. SOUZA JR., F.G., OLIVEIRA, Geiza E, ANZAI, Thiago, RICHA, Priscila, COSME, Tainá, NELE, Márcio, RODRIGUES, Cezar H. M, SOARES, Bluma G and PINTO, José Carlos. A Sensor for Acid Concentration Based on Cellulose Paper Sheets Modified with Polyaniline Nanoparticles. Macromolecular Materials and Engineering. v. 294, n. 11, p. 739-748. 2009. DOI 10.1002/mame.200900111. 0001 63. SOUZA JR., F.G., SOARES, B.G. and PINTO, J.C. Electrical surface resistivity of conductive polymers - A non-Gaussian approach for determination of confidence intervals. European Polymer Journal. v. 44, n. 11, p. 3908-3914. 2008. DOI 10.1016/j.eurpolymj.2008.07.022. 0000 64. SOUZA JR, F.G., SOARES, B.G., MANTOVANI, G.L., MANJUNATH, A., SOMASHEKARAPPA, H., 
SOMASHEKAR, R. and SIDDARAMAIAH. Blends of styrene butadiene styrene TRI block copolymer/polyaniline-Characterization by WAXS. Polymer. v. 47, n. 6, p. 2163-2171. 2006. DOI 10.1016/j.polymer.2006.01.033. 0000

65. SIDDARAMAIAH, SOUZA JR., F.G., SOARES, Bluma G and SOMASHEKAR, R. Investigation on microstructural behavior of styroflex/polyaniline blends by WAXS. Journal of Applied Polymer Science . v. 124, n. 6, p. 5097-5105. 2012. DOI 10.1002/app.35652. 0000

66. SOUZA JR., F.G. and SOARES, Bluma Guenther. Methodology for determination of Pani.DBSA content in conductive blends by using UV-Vis spectrometry. Polymer Testing. v. 25, n. 4, p. 512-517. 2006. DOI 10.1016/j.polymertesting.2006.01.014. 0000

67. SOUZA JR., F.G., PINTO, José C, RODRIGUES, Marcus V, ANZAI, Thiago K, RICHA, Priscila, MELO, Príamo A, NELE, Márcio, OLIVEIRA, Geiza E and SOARES, Bluma Guenther. New polyaniline/polycardanol conductive blends characterized by FTIR, NIR, and XPS. Polymer Engineering \& Science. v. 48, n. 10, p. 1947-1952. 2008. DOI 10.1002/pen.21047. 0004

68. SOUZA JR., F.G., ANZAl, Thiago Koichi, RODRIGUES, Marcus V. A, MELO JR., Príamo Albuquerque, NELE, Márcio and PINTO, José Carlos. In situ determination of aniline polymerization kinetics through near-infrared spectroscopy. Journal of Applied Polymer Science. v. 112, n. 1, p. 157-162. 2009. DOI 10.1002/app.29355. 0003

69. SOUZA JR., F.G., SOARES, Bluma G and DAHMOUCHE, Karim. Effect of preparation method on nanoscopic structure of conductive SBS/PANI blends: Study using small-angle X-ray scattering. Journal of Polymer Science Part B: Polymer Physics. v. 45, n. 22, p. 3069-3077. 2007. DOI 10.1002/polb.21305. 0006

70. SOARES, B., SOUZA JR., F.G., MANJUNATH, A., SOMASHEKARAPPA, H., SOMASHEKAR, R., and SIDDARAMAIAH. Variation of long periodicity in blends of styrene butadiene, styrene copolymer/polyaniline using small angle X-ray scattering data. Pramana. v. 69, n. 3, p. 435-443. 2007. DOI 10.1007/s12043007-0144-z. 0008

71. SOUZA JR., F.G., SOARES, B.G., SIDDARAMAIAH, MANJUNATH, A. and SOMASHEKAR, R. Blends of styrene-butadiene-styrene tri-block copolymer/polyaniline-Characterization by SAXS. Materials Science and Engineering: A. v. 476, n. 1-2, p. 240-247. 2008. DOI 10.1016/j.msea.2007.05.099. 0000 72. SIDDARAMAIAH, SOUZA JR., F.G., SOARES, Bluma G, PARAMESWARA, P. and SOMASHEKAR, R. Microstructural behaviors of polyaniline/CB Composites by SAXS. Journal of Applied Polymer Science. v. 116, n. 2, p. 673-679. 2010. DOI 10.1002/app.30904. 0000

73. GOMES, Fernando. Polyaniline: Trends and perspectives from text mining analysis. Brazilian Journal of Experimental Design, Data Analysis and Inferential Statistics. v. 1, n. 1, p. 9-39. 2021. DOI 10.29327/232092.1.1-8.

74. ZHAI, Dan-Dan, FANG, Zhen, JIN, Hongwei, HUI, Ming, KIRUBAHARAN, Christopher Joseph, YU, YangYang and YONG, Yang-Chun. Vertical alignment of polyaniline nanofibers on electrode surface for highperformance microbial fuel cells. Bioresource Technology. v. 288, p. 121499. 2019. DOI 
10.1016/j.biortech.2019.121499.

75. WANG, Xiaoning, WEI, Hongli, LIU, Xiuzhi, DU, Wei, ZHAO, Xiangjin and WANG, Xiaolin. Novel threedimensional polyaniline nanothorns vertically grown on buckypaper as high-performance supercapacitor electrode. Nanotechnology. v. 30, n. 32, p. 325401. 2019. DOI 10.1088/1361-6528/ab156d.

76. YELLAPPA, Masapogu, SRAVAN, J. Shanthi, SARKAR, Omprakash, REDDY, Y. V. Rami and MOHAN, S. Venkata. Modified conductive polyaniline-carbon nanotube composite electrodes for bioelectricity generation and waste remediation. Bioresource Technology. v. 284, p. 148-154. 2019. DOI 10.1016/j.biortech.2019.03.085.

77. HAIDER, Muhammad Rizwan, JIANG, Wen-Li, HAN, Jing-Long, SHARIF, Hafiz Muhammad Adeel, DING, Yang-Cheng, CHENG, Hao-Yi and WANG, Ai-Jie. In-situ electrode fabrication from polyaniline derived Ndoped carbon nanofibers for metal-free electro-Fenton degradation of organic contaminants. Applied

Catalysis B: Environmental. v. 256, p. 117774. 2019. DOI

https://doi.org/10.1016/j.apcatb.2019.117774.

78. CHEN, Shaoyun, LIU, Ben, ZHANG, Xingying, CHEN, Fang, SHI, Hong, HU, Chenglong and CHEN, Jian. Growth of polyaniline on TiO2 tetragonal prism arrays as electrode materials for supercapacitor.

Electrochimica Acta. v. 300, p. 373-379. 2019. DOI https://doi.org/10.1016/j.electacta.2019.01.110. 79. YANILMAZ, Meltem, DIRICAN, Mahmut, ASIRI, Abdullah M. and ZHANG, Xiangwu. Flexible polyanilinecarbon nanofiber supercapacitor electrodes. Journal of Energy Storage. v. 24, p. 100766. 2019. DOI 10.1016/j.est.2019.100766.

80. SMIRNOV, Michael A., TARASOVA, Elvira V., VOROBIOV, Vitaly K., KASATKIN, Igor A., MIKLI, Valdek, SOKOLOVA, Maria P., BOBROVA, Natalya V., VASSILJEVA, Viktoria, KRUMME, Andres and YAKIMANSKIY, Alexander V. Electroconductive fibrous mat prepared by electrospinning of polyacrylamide-g-polyaniline copolymers as electrode material for supercapacitors. Journal of Materials Science. v. 54, n. 6, p. 48594873. 2019. DOI 10.1007/s10853-018-03186-w.

81. WANG, Jianying, JI, Lvlv, TENG, Xue, LIU, Yangyang, GUO, Lixia and CHEN, Zuofeng. Decoupling halfreactions of electrolytic water splitting by integrating a polyaniline electrode. Journal of Materials Chemistry A. v. 7, n. 21, p. 13149-13153. 2019. DOI 10.1039/C9TA03285A.

82. LI, Jianpeng, XIAO, Dingshu, REN, Yaqi, LIU, Huiru, CHEN, Zhenxuan and XIAO, Jiaming. Bridging of adjacent graphene/polyaniline layers with polyaniline nanofibers for supercapacitor electrode materials. Electrochimica Acta. v. 300, p. 193-201. 2019. DOI 10.1016/j.electacta.2019.01.089. 83. RIBEIRO, Caroline, SCHEUFELE, Fabiano Bisinella, ESPINOZA-QUIÑONES, Fernando Rodolfo, MÓDENES, Aparecido Nivaldo, VIEIRA, Melissa Gurgel Adeodato, KROUMOV, Alexander Dimitrov and BORBA, Carlos Eduardo. A comprehensive evaluation of heavy metals removal from battery industry wastewaters by applying bio-residue, mineral and commercial adsorbent materials. Journal of Materials Science. P. 120. 2018. DOI 10.1007/s10853-018-2150-6.

84. SUN, Dan-Dan, HAN, Jia-Jun, MA, Hui, ZHANG, Ning, HAN, Tao and CHENG, Jin-Ning. Synthesis of polyaniline and application of hydrophobic breathable structure in zinc-polyaniline battery. Ionics. P. 1-8. 
2019.

85. JIN, Hongchang, ZHANG, Taiming, CHUANG, Chenghao, LU, Ying-Rui, CHAN, Ting-Shan, DU, Zhenzhen, Jl, Hengxing and WAN, Li-jun. Synergy of Black Phosphorus-Graphite-Polyaniline Based Ternary Composite for Stable High Reversible Capacity Na-ion Battery Anodes. ACS applied materials \& interfaces . 2019. 86. LAI, Xiangwan, HU, Guorong, PENG, Zhongdong, TONG, Hui, LU, Yan, WANG, Yongzhi, QI, Xianyue, XUE, Zhichen, HUANG, Yong and DU, Ke. Surface structure decoration of high capacity Li1. 2Mn0. 54Ni0. $13 \mathrm{CoO}$. 1302 cathode by mixed conductive coating of Li1. 4AI0. 4Ti1. 6 (PO4) 3 and polyaniline for lithium-ion batteries. Journal of Power Sources. v. 431, p. 144-152. 2019.

87. WEI, Yiqi, YAN, Yinglin, ZOU, Yiming, SHI, Mangmang, DENG, Qijiu, ZHAO, Nana, WANG, Juan, YOU, Caiyin, YANG, Rong and XU, Yunhua. Sulfonated polyaniline coated bamboo-derived biochar/sulfur cathode for Li-S batteries with excellent dual conductivity and polysulfides affinity. Electrochimica Acta. v. 310, p. 45-57. 2019.

88. MI, Hongwei, YANG, Xiaodan, LI, Fang, ZHUANG, Xiaoqin, CHEN, Chunxia, LI, Yongliang and ZHANG, Peixin. Self-healing silicon-sodium alginate-polyaniline composites originated from the enhancement hydrogen bonding for lithium-ion battery: A combined simulation and experiment study. Journal of Power Sources. v. 412, p. 749-758. 2019. DOI https://doi.org/10.1016/j.jpowsour.2018.11.034.

89. LI, Xianwei, LV, Ruihua, ZOU, Shufen, NA, Bing, LIU, Pengfei, MA, Yue and LIU, Hesheng. Polyaniline nanopillars on surface cracked carbon fibers as an ultrahigh-performance cathode for a flexible rechargeable aqueous Zn-ion battery. Composites Science and Technology. v. 180, p. 71-77. 2019. 90. HAN, Haixia, LU, Haiyan, JIANG, Xiaoyu, ZHONG, Faping, Al, Xinping, YANG, Hanxi and CAO, Yuliang. Polyaniline hollow nanofibers prepared by controllable sacrifice-template route as high-performance cathode materials for sodium-ion batteries. Electrochimica Acta. v. 301, p. 352-358. 2019.

91. LUO, Yani, GUO, Ruisong, LI, Tingting, LI, Fuyun, LIU, Zhichao, ZHENG, Mei, WANG, Baoyu, YANG, Zhiwei, LUO, Honglin and WAN, Yizao. Application of Polyaniline for Li-lon Batteries, Lithium-Sulfur Batteries, and Supercapacitors. ChemSusChem. v. 12, n. 8, p. 1591-1611. 2019.

92. ZHANG, Fan, XIONG, Pan, GUO, Xin, ZHANG, Jinqiang, YANG, Wang, WU, Wenjian, LIU, Hao and WANG, Guoxiu. A nitrogen, sulphur dual-doped hierarchical porous carbon with interconnected conductive polyaniline coating for high-performance sodium-selenium batteries. Energy Storage Materials. v. 19, p. 251-260. 2019. DOI https://doi.org/10.1016/j.ensm.2019.03.019.

93. CHEN, Shaoyun, LIU, Ben, WANG, Yuan, CHENG, Huan, ZHANG, Xingying, XU, Shaoqin, LIU, Hui, LIU, Wenfeng and HU, Chenglong. Excellent Electrochemical Performances of Intrinsic Polyaniline Nanofibers Fabricated by Electrochemical Deposition. Journal of Wuhan University of Technology-Mater. Sci. Ed. v. 34, n. 1, p. 216-222. 2019. DOI 10.1007/s11595-019-2038-6.

94. GOSWAMI, Sumita, SANTOS, Andreia dos, NANDY, Suman, IGREJA, Rui, BARQUINHA, Pedro, MARTINS, Rodrigo and FORTUNATO, Elvira. Human-motion interactive energy harvester based on polyaniline functionalized textile fibers following metal/polymer mechano-responsive charge transfer mechanism. Nano Energy. v. 60, p. 794-801. 2019. DOI https://doi.org/10.1016/j.nanoen.2019.04.012. 
95. LAPKIN, D. A., MALAKHOV, S. N., DEMIN, V. A., CHVALUN, S. N. and FEIGIN, L. A. Hybrid polyaniline/polyamide- 6 fibers and nonwoven materials for assembling organic memristive elements. Synthetic Metals. v. 254, p. 63-67. 2019. DOI 10.1016/j.synthmet.2019.05.016.

96. HUANG, Jingxia, WANG, Honggang, LI, Zhangpeng, WU, Xianzhang, WANG, Jinqing and YANG, Shengrong. Improvement of piezoresistive sensing behavior of graphene sponge by polyaniline nanoarrays. Journal of Materials Chemistry C. v. 7, n. 24, p. 7386-7394. 2019. DOI 10.1039/C9TC01659G. 97. MOLJI, C., RENJITH, S., JINESH, K. B. and SUDHA, J. D. Macroscopically oriented (3-pentadecyl phenol) dangled fluorene based conductive polymer through side chain engineering for microelectronics. Express Polymer Letters; Budapest. v. 13, n. 12, p. 1027-1040. 2019. DOI

http://dx.doi.org/10.3144/expresspolymlett.2019.90.

98. FARIA, A. M. A., MIRANDA, M. A., GONÇALVES, G. E., BIANCHI, R. F., BIANCHI, A. G. C., CUBA, C., NEVES, B. R. A. and PINTO, E. S. Partially ordered porous structures on layer-by-layer polyaniline/poly(vinyl sulfate sodium) ultrathin films: Easy fabrication of robust submicroscopic patterning. Journal of Applied Polymer Science. v. n/a, n. n/a, p. 48597. DOI 10.1002/app.48597.

99. MOHAMMADI, Behzad, PIRSA, Sajad and ALIZADEH, Mohammad. Preparing chitosan-polyaniline nanocomposite film and examining its mechanical, electrical, and antimicrobial properties. Polymers and Polymer Composites. v. 27, n. 8, p. 507-517. 2019. DOI 10.1177/0967391119851439.

100. SHAH, Mutabar, KHAN, Noman, IMRAN, Zahid, KHAN, Masood, KHATTAK, Abraiz, KHAN, Adam and ULLAH, Niamat. Structural, optical and impedance spectroscopy study of thin film of polyaniline (PANI/ZnO) nanocomposite. Materials Research Express [online]. 2019. DOI 10.1088/2053-1591/ab5d7e. Available from: http://iopscience.iop.org/10.1088/2053-1591/ab5d7e. Accessed 5 December 2019.

101. ENAD, Abdulsattar Gh, ABDULLAH, Estabraq T. and HAMED, Mohammed Gh. Study the Electrical Properties of Carbon Nanotubes/Polyaniline Nanocomposites. Journal of Physics: Conference Series. v. 1178, p. 012032. 2019. DOI 10.1088/1742-6596/1178/1/012032.

102. YANG, Ming, LI, Jian and XIE, Wenfeng. Preparation, Antibacterial and Antistatic Properties of PP/AgMs/CB Composites. Journal of Wuhan University of Technology-Mater. Sci. Ed. v. 33, n. 3, p. 749757. 2018. DOI 10.1007/s11595-018-1888-7.

103. GHORBANI, Mohsen, FAZLI, Shiva and LASHKENARI, Mohammad Soleimani. Fabrication of PMMA/PANI/Fe3O4 as a Novel Conducting Hybrid Coating. Polymer-Plastics Technology and Engineering. v. 57, n. 6, p. 591-599. 2018. DOI 10.1080/03602559.2017.1332205.

104. BAYAT, Maryam, IZADAN, Hossein, MOLINA, Brenda G., SÁNCHEZ, Margarita, SANTIAGO, Sara, SEMNANI, Dariush, DINARI, Mohammad, GUIRADO, Gonzalo, ESTRANY, Francesc and ALEMÁN, Carlos. Electrochromic Self-Electrostabilized Polypyrrole Films Doped with Surfactant and Azo Dye. Polymers. v. 11, n. 11, p. 1757. 2019. DOI 10.3390/polym11111757.

105. RADI, Abd-Egawad, WAHDAN, Tarek and EL-BASIONY, Amir. Electrochemical Sensors Based on Molecularly Imprinted Polymers for Pharmaceuticals Analysis. Current Analytical Chemistry. v. 15, n. 3, p. 219-239. 2019. DOI 10.2174/1573411014666180501100131. 
106. KUO, Chung-Wen, CHANG, Jui-Cheng, LEE, Po-Ying, WU, Tzi-Yi and HUANG, Yu-Chang. Applications of Electrochromic Copolymers Based on Tris(4-carbazoyl-9-ylphenyl)amine and Bithiophene Derivatives in Electrochromic Devices. Materials. v. 11, n. 10, p. 1895. 2018. DOI 10.3390/ma11101895.

107. KUO, Chung-Wen, CHANG, Jui-Cheng, HUANG, Yu-Ting, CHANG, Jeng-Kuei, LEE, Li-Ting and WU, Tzi-Yi. Applications of Copolymers Consisting of 2,6-di(9H-carbazol-9-yl)pyridine and 3,6-di(2-thienyl)carbazole Units as Electrodes in Electrochromic Devices. Materials. v. 12, n. 8, p. 1251. 2019. DOI $10.3390 / \mathrm{ma12081251.}$

108. ALESANCO, Yolanda, VIÑUALES, Ana, RODRIGUEZ, Javier and TENA-ZAERA, Ramón. All-in-One GelBased Electrochromic Devices: Strengths and Recent Developments. Materials. v. 11, n. 3, p. 414. 2018. DOI 10.3390/ma11030414.

109. JAHANDARI, Shokoofe, TAHER, Mohammad Ali and KARIMI-MALEH, Hassan. A first adrenalone electrochemical sensor using a gold-nanoparticle/poly(pyrrole) composite-modified graphite electrode. Analytical Methods. v. 11, n. 20, p. 2658-2662. 2019. DOI 10.1039/C8AY02765J.

110. ABDALI, Hanan, HELI, Bentolhoda and AJJI, Abdellah. Cellulose Nanopaper Cross-Linked Amino Graphene/Polyaniline Sensors to Detect CO2 Gas at Room Temperature. Sensors. v. 19, n. 23, p. 5215. 2019. DOI 10.3390/s19235215.

111. KULIKOVA, Tatjana, PORFIREVA, Anna, EVTUGYN, Gennady and HIANIK, Tibor. Electrochemical DNA Sensors with Layered Polyaniline-DNA Coating for Detection of Specific DNA Interactions. Sensors. v. 19, n. 3, p. 469. 2019. DOI 10.3390/s19030469.

112. SHOAIE, Nahid, DANESHPOUR, Maryam, AZIMZADEH, Mostafa, MAHSHID, Sara, KHOSHFETRAT, Seyyed Mehdi, JAHANPEYMA, Fatemeh, GHOLAMINEJAD, Alieh, OMIDFAR, Kobra and FORUZANDEH, Mehdi. Electrochemical sensors and biosensors based on the use of polyaniline and its nanocomposites: a review on recent advances. Microchimica Acta. v. 186, n. 7, p. 465. 2019. DOI 10.1007/s00604-019-3588-1. 113. NASIRIAN, Shahruz. Enhanced carbon dioxide sensing performance of polyaniline/tin dioxide nanocomposite by ultraviolet light illumination. Applied Surface Science. v. 502, p. 144302. 2020. DOI 10.1016/j.apsusc.2019.144302.

114. KULKARNI, S. B., NAVAlE, Y. H., NAVALE, S. T., STADLER, F. J., RAMGIR, N. S. and PATIL, V. B. Hybrid polyaniline-WO3 flexible sensor: A room temperature competence towards NH3 gas. Sensors and Actuators B: Chemical. v. 288, p. 279-288. 2019. DOI https://doi.org/10.1016/j.snb.2019.02.094. 115. LIU, Kangning, ZHOU, Ziqiang, YAN, Xingwu, MENG, Xiang, TANG, Hua, QU, Konggang, GAO, Yuanyuan, LI, Ying, YU, Junsheng and LI, Lu. Polyaniline Nanofiber Wrapped Fabric for High Performance Flexible Pressure Sensors. Polymers. v. 11, n. 7, p. 1120. 2019. DOI 10.3390/polym11071120. 116. KULKARNI, S. B., NAVALE, Y. H., NAVALE, S. T., STADLER, F. J. and PATIL, V. B. Room temperature ammonia gas sensing properties of polyaniline nanofibers. Journal of Materials Science: Materials in Electronics. v. 30, n. 9, p. 8371-8380. 2019. DOI 10.1007/s10854-019-01154-x.

117. GICEVICIUS, Mindaugas, KUCINSKI, Juzef, RAMANAVICIENE, Almira and RAMANAVICIUS, Arunas. Tuning the optical pH sensing properties of polyaniline-based layer by electrochemical copolymerization of 
aniline with o-phenylenediamine. Dyes and Pigments. v. 170, p. 107457. 2019. DOI

10.1016/j.dyepig.2019.04.002.

118. HONG, Jianhan, HU, Chengye, JIN, Lihua, HAN, Xiao, YAO, Juming and GALI, Ignacio Gil. Conductive polyaniline-coated poly ( $p$-phenylenetere phthamide) yarn-reinforced multiaxial composites for electromagnetic shielding. Journal of Industrial Textiles. P. 1528083719883048. 2019.

119. MEHER, D., KARNA, N. and SAHOO, B. P. Development of Poly (vinylidene fluoride) and Polyaniline blend with high dielectric permittivity, excellent electromagnetic shielding effectiveness and Ultra low optical energy band gap: Effect of ionic liquid and temperature. Polymer. v. 181, p. 121759. 2019. 120. MOHAN, Ranjini R., VARMA, Sreekanth J. and JAYALEKSHMI, S. Effective Electromagnetic Shield using Conductive Polyaniline Films. Materials Today: Proceedings. v. 8, p. 371-378. 2019.

121. LU, Hao, LIAO, Bangquan, WANG, Haibo, XU, Zhiwei, LI, Nan, LIU, Liangsen, ZHANG, Xingxiang and WU, Ning. Electromagnetic shielding of ultrathin, lightweight and strong nonwoven composites decorated by a bandage-style interlaced layer electropolymerized with polyaniline. Journal of Materials Science: Materials in Electronics. P. 1-12. 2019.

122. ZHANG, Yali, WANG, Lei, ZHANG, Junliang, SONG, Ping, XIAO, Zhuorui, LIANG, Chaobo, QIU, Hua, KONG, Jie and GU, Junwei. Fabrication and investigation on the ultra-thin and flexible Ti3C2Tx/co-doped polyaniline electromagnetic interference shielding composite films. Composites Science and Technology. v. 183, p. 107833. 2019.

123. ZHANG, Kun, GU, Xue, DAI, Qian, YUAN, Bingnan, YAN, Yue and GUO, Minghui. Flexible polyanilinecoated poplar fiber composite membranes with effective electromagnetic shielding performance. Vacuum. v. 170, p. 108990. 2019.

124. WANG, Yu, WANG, Wei, DING, Xiaodong and YU, Dan. Multilayer-structured Ni-Co-FeP/polyaniline/polyimide composite fabric for robust electromagnetic shielding with low reflection characteristic. Chemical Engineering Journal. v. 380, p. 122553. 2020.

125. OMURA, Taku, CHAN, Chi Hoong, WAKISAKA, Minato and NISHIDA, Haruo. Organic Thin Paper of Cellulose Nanofiber/Polyaniline Doped with (\$lpm\$)-10-Camphorsulfonic Acid Nanohybrid and Its Application to Electromagnetic Shielding. ACS Omega. v. 4, n. 5, p. 9446-9452. 2019.

126. ZHANG, Yang, YANG, Zhangjing, YU, Ying, WEN, Bianying, LIU, Yiyang and QIU, Munan. Tunable Electromagnetic Interference Shielding Ability in a One-Dimensional Bagasse Fiber/Polyaniline Heterostructure. ACS Applied Polymer Materials. v. 1, n. 4, p. 737-745. 2019. 127. MOHAN, Velram Balaji, SANTHANA KRISHNAN, Sushmitha and BHATTACHARYYA, Debes. Manufacturing and characterization of novel silicone/natural fabric/graphene-based functional composites for human body motion sensing. Polymer Composites. v. 42, n. 7, p. 3493-3507. 2021. DOI 10.1002/pc.26074.

128. VAN ECK, Nees Jan and WALTMAN, Ludo. Software survey: VOSviewer, a computer program for bibliometric mapping. Scientometrics. v. 84, n. 2, p. 523-538. 2010. DOI 10.1007/s11192-009-0146-3. 129. JONATHON LOVE, DAMIAN DROPMANN, RAVI SELKER, MARCELLO GALLUCCI, SEBASTIAN JENTSCHKE, 
and SERDAR BALCI. The jamovi project [online]. 2021. Accessed 17 August 2021. Available from: https://www.jamovi.org.

130. VIECHTBAUER, Wolfgang. Bias and Efficiency of Meta-Analytic Variance Estimators in the RandomEffects Model. Journal of Educational and Behavioral Statistics . v. 30, n. 3, p. 261-293. 2005. DOI 10.3102/10769986030003261.

131. COCHRAN, William G. The Combination of Estimates from Different Experiments. Biometrics. v. 10, n. 1, p. 101-129. 1954. DOI 10.2307/3001666.

132. CHOI, S.R., SO, I.-S., LEE, S.W., YOO, J., SEO, Y.-S., CHO, H.-S. and PARK, J.-Y. 3D architecture double perovskite $\mathrm{NdBa} 0.5 \mathrm{Sr} 0.5 \mathrm{Co1} .5 \mathrm{Fe} 0.5 \mathrm{O} 5+\delta$ embedded hollow-net $\mathrm{Co} 3 \mathrm{O} 4$ bifunctional electrocatalysts coupled with N-doped CNT and reduced graphene oxide for oxygen electrode reactions. Journal of Alloys and Compounds [online]. v. 823. 2020. DOI 10.1016/j.jallcom.2020.153782. Available from:

https://www.scopus.com/inward/record.uri?eid=2-s2.0-

85077917424\&doi=10.1016\%2fj.jallcom.2020.153782\&partnerlD=40\&md5=95f34c4ac2463d53f39acfded3 fc6d30. Scopus

133. NIU, Z., LUAN, P., SHAO, Q., DONG, H., LI, J., CHEN, J., ZHAO, D., CAI, L., ZHOU, W., CHEN, X. and XIE, S. A "skeleton/skin" strategy for preparing ultrathin free-standing single-walled carbon nanotube/polyaniline films for high performance supercapacitor electrodes. Energy and Environmental Science. v. 5, n. 9, p. 8726-8733. 2012. DOI 10.1039/c2ee22042c. Scopus

134. IBRAHIM, Nada I. and WASFI, Ahmed S. A comparative study of polyaniline/MWCNT with polyaniline/SWCNT nanocomposite films synthesized by microwave plasma polymerization. Synthetic Metals. v. 250, p. 49-54. 2019. DOI https://doi.org/10.1016/j.synthmet.2019.02.007.

135. LIU, X., LIANG, Y., YUE, G., TU, Y. and ZHENG, H. A dual function of high efficiency quasi-solid-state flexible dye-sensitized solar cell based on conductive polymer integrated into poly (acrylic acid-co-carbon nanotubes) gel electrolyte. Solar Energy. v. 148, p. 63-69. 2017. DOI 10.1016/j.solener.2017.03.070. Scopus

136. LIU, Y., LI, J., LI, F., LI, W., YANG, H., ZHANG, X., LIU, Y. and MA, J. A facile preparation of CoFe2O4 nanoparticles on polyaniline-functionalised carbon nanotubes as enhanced catalysts for the oxygen evolution reaction. Journal of Materials Chemistry A. v. 4, n. 12, p. 4472-4478. 2016. DOI 10.1039/c5ta10420c. Scopus

137. BROOK, I., MECHREZ, G., SUCKEVERIENE, R.Y., TCHOUDAKOV, R. and NARKIS, M. A novel approach for preparation of conductive hybrid elastomeric nano-composites. Polymers for Advanced Technologies . v. 24, n. 8, p. 758-763. 2013. DOI 10.1002/pat.3142. Scopus

138. ZHANG, C., TJIU, W.W. and LIU, T. All-carbon composite paper as a flexible conducting substrate for the direct growth of polyaniline particles and its applications in supercapacitors. Polymer Chemistry. v. 4, n. 24, p. 5785-5792. 2013. DOI 10.1039/c3py00699a. Scopus 139. FU, X., LI, Z., XU, L., LIAO, M., SUN, H., XIE, S., SUN, X., WANG, B. and PENG, H. Amphiphilic coresheath structured composite fiber for comprehensively performed supercapacitor. Science China 
Materials. v. 62, n. 7, p. 955-964. 2019. DOI 10.1007/s40843-018-9408-3. Scopus

140. ALMASI, M. J., SHEIKHOLESLAMI, T. Fanaei and NAGHDI, M. R. Band gap study of polyaniline and polyaniline/MWNT nanocomposites with in situ polymerization method. Composites Part B:

Engineering. v. 96, p. 63-68. 2016. DOI https://doi.org/10.1016/j.compositesb.2016.04.032.

141. SHA, Rinky and BADHULIKA, Sushmee. Binder free platinum nanoparticles decorated graphenepolyaniline composite film for high performance supercapacitor application. Electrochimica Acta. v. 251, p. 505-512. 2017. DOI https://doi.org/10.1016/j.electacta.2017.08.140.

142. KHANDELWAL, Vinay, SAHOO, Sushanta K., KUMAR, Ashok, SETHI, Sushanta K. and MANIK, Gaurav. Bio-sourced electrically conductive epoxidized linseed oil based composites filled with polyaniline and carbon nanotubes. Composites Part B: Engineering. v. 172, p. 76-82. 2019. DOI https://doi.org/10.1016/j.compositesb.2019.05.050.

143. MENG, F., ZHAO, J., YE, Y., ZHANG, X. and LI, Q. Carbon nanotube fibers for electrochemical applications: Effect of enhanced interfaces by an acid treatment. Nanoscale. v. 4, n. 23, p. 7464-7468. 2012. DOI 10.1039/c2nr32332j. Scopus

144. CHEN, P.-Y., DORVAL COURCHESNE, N.-M., HYDER, M.N., QI, J., BELCHER, A.M. and HAMMOND, P.T. Carbon nanotube-polyaniline core-shell nanostructured hydrogel for electrochemical energy storage. RSC Advances. v. 5, n. 48, p. 37970-37977. 2015. DOI 10.1039/c5ra02944a. Scopus 145. REBELO, A.M.R., LIU, Y., LIU, C., SCHÄFER, K.-H., SAUMER, M. and YANG, G. Carbon NanotubeReinforced Poly(4-vinylaniline)/Polyaniline Bilayer-Grafted Bacterial Cellulose for Bioelectronic Applications. ACS Biomaterials Science and Engineering. v. 5, n. 5, p. 2160-2172. 2019. DOI 10.1021/acsbiomaterials.9b00039. Scopus 146. MAO, T., TANG, Y., ZHANG, Y., ZHANG, J. and GUO, D. Carbon nanotubes/polyaniline nanocomposite coatings: Preparation, rheological behavior, and their application in paper surface treatment. Journal of Applied Polymer Science [online]. v. 135, n. 23. 2018. DOI 10.1002/app.46329. Available from: https://www.scopus.com/inward/record.uri?eid=2-s2.085043584358\&doi=10.1002\%2fapp.46329\&partnerID=40\&md5=0e10dbdfc33a4237e8ecf8250cd0cb10. Scopus

147. WASFI, A.S. and ISMAEL, H.O. Characterization of polyaniline/single-walled carbon nanotube composite films prepared by plasma polymerization. Acta Physica Polonica A. v. 135, n. 4, p. 578-582. 2019. DOI 10.12693/APhysPolA.135.578. Scopus 148. KAEWSAI, D. and HUNSOM, M. Comparative study of the orr activity and stability of pt and ptm ( $M=$ $\mathrm{ni}, \mathrm{co}, \mathrm{cr}, \mathrm{pd}$ ) supported on polyaniline/carbon nanotubes in a pem fuel cell. Nanomaterials [online]. $\mathrm{v}$. 8, n. 5. 2018. DOI 10.3390/nano8050299. Available from: https://www.scopus.com/inward/record.uri? eid $=2$-s2.085047668404\&doi=10.3390\%2fnano8050299\&partnerID=40\&md5=1a947c46f6827f33a7c0df6f3f367a8d. Scopus

149. PIERINI, F., LANZI, M., LESCI, I.G. and ROVERI, N. Comparison between inorganic geomimetic 
chrysotile and multiwalled carbon nanotubes in the preparation of one-dimensional conducting polymer nanocomposites. Fibers and Polymers. v. 16, n. 2, p. 426-433. 2015. DOI 10.1007/s12221-015-0426-x. Scopus

150. ChATtERJEE, M.J., BANERJEE, D. and CHATTERJEE, K. Composite of single walled carbon nanotube and sulfosalicylic acid doped polyaniline: A thermoelectric material. Materials Research Express [online]. v. 3, n. 8. 2016. DOI 10.1088/2053-1591/3/8/085009. Available from:

https://www.scopus.com/inward/record.uri?eid=2-s2.0-84987668086\&doi=10.1088\%2f20531591\%2f3\%2f8\%2f085009\&partnerID=40\&md5=5d4bde2d8c4c4fee471aa7ec09bbdd30. Scopus 151. ZHOU, D., SONG, W.-L., LI, X. and FAN, L.-Z. Confined Porous Graphene/SnOx Frameworks within Polyaniline-Derived Carbon as Highly Stable Lithium-Ion Battery Anodes. ACS Applied Materials and Interfaces. v. 8, n. 21, p. 13410-13417. 2016. DOI 10.1021/acsami.6b01875. Scopus 152. HASAN, M., HOSSAIN, M.M. and LEE, M. DC electrical conductivity retention and thermo-optical studies of camphor sulfonic acid doped cetyl tri methyl ammonium bromide-assisted graphene/polyaniline composite nanofibers. Journal of Industrial and Engineering Chemistry . v. 32, p. 123-127. 2015. DOI 10.1016/j.jiec.2015.08.007. Scopus

153. GHAZALI, S., HOSSAIN, M.M., KHAN, A., KHAN, M.Y. and HASAN, M. DC Electrical Conductivity Retention, Optical Properties and Ammonia Sensing Analysis of Naturally Degraded CSA-Doped Graphene/polyaniline Composite Nanofibers Prepared with CTAB. Journal of Electronic Materials. v. 46, n. 1, p. 331-339. 2017. DOI 10.1007/s11664-016-4922-6. Scopus

154. SHALINI, V., NAVANEETHAN, M., HARISH, S., ARCHANA, J., PONNUSAMY, S., IKEDA, H. and HAYAKAWA, Y. Design and fabrication of PANI/GO nanocomposite for enhanced room-temperature thermoelectric application. Applied Surface Science. v. 493, p. 1350-1360. 2019. DOI https://doi.org/10.1016/j.apsusc.2019.06.249.

155. XIE, A., TAO, F., SUN, W., LI, Y., JIANG, C., HU, L., ZHAO, J., LUO, S. and YAO, C. Design and synthesis of graphene/porous polyaniline nanocomposite using attapulgite as template for high-performance supercapacitors. Journal of the Electrochemical Society. v. 164, n. 2, p. H70-H77. 2017. DOI 10.1149/2.1021702jes. Scopus 156. WANG, H., WANG, L., WANG, R., TIAN, X. and ZHENG, K. Design and synthesis of the polyaniline interface for polyamide 66/multi-walled carbon nanotube electrically conductive composites. Colloid and Polymer Science. v. 291, n. 4, p. 1001-1007. 2013. DOI 10.1007/s00396-012-2822-8. Scopus 157. SHARMA, S., KUMAR, V., PATHAK, A.K., YOKOZEKI, T., YADAV, S.K., SINGH, V.N., DHAKATE, S.R. and SINGH, B.P. Design of MWCNT bucky paper reinforced PANI-DBSA-DVB composites with superior electrical and mechanical properties. Journal of Materials Chemistry C. v. 6, n. 45, p. 12396-12406. 2018. DOI 10.1039/C8TC04023K. Scopus

158. PONNAMMA, D., SADASIVUNI, K.K., STRANKOWSKI, M., KASAK, P., KRUPA, I. and ALMAADEED, M.A.-A. Eco-Friendly Electromagnetic Interference Shielding Materials from Flexible Reduced Graphene Oxide Filled Polycaprolactone/Polyaniline Nanocomposites. Polymer - Plastics Technology and Engineering . v. 55, 
n. 9, p. 920-928. 2016. DOI 10.1080/03602559.2015.1132435. Scopus

159. GULL, N., KHAN, S.M., ISLAM, A., ZIA, S., SHAFIQ, M., SABIR, A., MUNAWAR, M.A., BUTT, M.T.Z. and JAMIL, T. Effect of different oxidants on polyaniline/single walled carbon nanotubes composites synthesized via ultrasonically initiated in-situ chemical polymerization. Materials Chemistry and Physics. v. 172, p. 39-46. 2016. DOI 10.1016/j.matchemphys.2015.12.048. Scopus

160. TANG, Y., HU, X., LIU, D., GUO, D. and ZHANG, J. Effect of microwave treatment of graphite on the electrical conductivity and electrochemical properties of polyaniline/graphene oxide composites. Polymers [online]. v. 8, n. 11. 2016. DOI 10.3390/polym8110399. Available from:

https://www.scopus.com/inward/record.uri?eid=2-s2.0-

84999751765\&doi=10.3390\%2fpolym8110399\&partnerlD=40\&md5=713ce4f84abe49eb92ac9ed3596c842

b. Scopus

161. YUN, J., IM, J.S., KIM, H.-I. and LEE, Y.-S. Effect of oxyfluorination on electromagnetic interference shielding of polyaniline-coated multi-walled carbon nanotubes. Colloid and Polymer Science. v. 289, n. 15-16, p. 1749-1755. 2011. DOI 10.1007/s00396-011-2496-7. Scopus

162. RAZAK, S.I.A., ZEIN, S.H.S. and AHMAD, A.L. Effect of para-hydroxybenzene sulfonic acid on the properties of ine/multiwalled carbon nanotubes-MnO2. Nano. v. 5, n. 6, p. 369-373. 2010. DOI 10.1142/S1793292010002293. Scopus

163. REN, Y., PAN, D., LI, X., FU, F., ZHAO, Y. and WANG, X. Effect of polyaniline-graphene nanosheets modified cathode on the performance of sediment microbial fuel cell. Journal of Chemical Technology and Biotechnology. v. 88, n. 10, p. 1946-1950. 2013. DOI 10.1002/jctb.4146. Scopus

164. KHONG, C.H., TEH, G.B. and PHANG, S.W. Effect of Titanium Dioxide and Carbon Nanotubes on Polyaniline Nanocomposites for Heavy Metals Removal. Macromolecular Symposia [online]. v. 382, n. 1. 2018. DOI 10.1002/masy.201800087. Available from: https://www.scopus.com/inward/record.uri?eid=2s2.0-

85058824694\&doi $=10.1002 \% 2$ fmasy $.201800087 \&$ partnerlD $=40 \& m d 5=e 474781207$ e376a5fd98c114005f3 157. Scopus

165. BAE, S.H., LAYEK, R.K., LEE, S.H., KUILA, T., KIM, N.H. and LEE, J.H. Effects of the reduction of PAnicoated oxidized multiwall carbon nanotubes on the positive temperature coefficient behaviors of their carbon black/high density polyethylene composites. Polymer Testing. v. 50, p. 83-93. 2016. DOI 10.1016/j.polymertesting.2016.01.001. Scopus

166. PARK, O.-K., KIM, N.H., YOO, G.-H., RHEE, K.Y. and LEE, J.H. Effects of the surface treatment on the properties of polyaniline coated carbon nanotubes/epoxy composites. Composites Part B: Engineering . v. 41, n. 1, p. 2-7. 2010. DOI 10.1016/j.compositesb.2009.10.002. Scopus

167. YUAN, B., WANG, B., HU, Y., MU, X., HONG, N., LIEW, K.M. and HU, Y. Electrical conductive and graphitizable polymer nanofibers grafted on graphene nanosheets: Improving electrical conductivity and flame retardancy of polypropylene. Composites Part A: Applied Science and Manufacturing . v. 84, p. 76-86. 2016. DOI 10.1016/j.compositesa.2016.01.003. Scopus 
168. SANTOS, João Paulo Ferreira, ARJMAND, Mohammad, MELO, Guilherme Henrique França, CHIZARI, Kambiz, BRETAS, Rosario Elida Suman and SUNDARARAJ, Uttandaraman. Electrical conductivity of electrospun nanofiber mats of polyamide 6/polyaniline coated with nitrogen-doped carbon nanotubes. Materials \& Design. v. 141, p. 333-341. 2018. DOI https://doi.org/10.1016/j.matdes.2017.12.052. 169. A.P., S., P.S., S. and NARAYANANKUTTY, S.K. Electrical, thermal, mechanical and electromagnetic interference shielding properties of PANI/FMWCNT/TPU composites. Progress in Organic Coatings. v. 113, p. 168-174. 2017. DOI 10.1016/j.porgcoat.2017.09.001. Scopus

170. CHOI, Hyun-Jung, JEON, In-Yup, KANG, Sang-Wook and BAEK, Jong-Beom. Electrochemical activity of a polyaniline/polyaniline-grafted multiwalled carbon nanotube mixture produced by a simple suspension polymerization. Electrochimica Acta. v. 56, n. 27, p. 10023-10031. 2011. DOI https://doi.org/10.1016/j.electacta.2011.08.103.

171. ALIPOUR, A., LAKOURAJ, M.M., OJANI, R., ROUDBARI, M.N., CHAICHI, M.J. and NEMATI, A.

Electrochemical and chemiluminescence properties of polyaniline/pectin hybrid nanocomposites based on graphene and CdS nanoparticles. Polymer Testing. v. 76, p. 490-498. 2019. DOI 10.1016/j.polymertesting.2019.04.013. Scopus

172. GORDUK, O., GENCTEN, M., GORDUK, S., SAHIN, M. and SAHIN, Y. Electrochemical fabrication and supercapacitor performances of metallo phthalocyanine/functionalized-multiwalled carbon nanotube/polyaniline modified hybrid electrode materials. Journal of Energy Storage [online]. v. 33. 2021. DOI 10.1016/j.est.2020.102049. Available from: https://www.scopus.com/inward/record.uri?eid=2s2.0-

85096880176\&doi=10.1016\%2fj.est.2020.102049\&partnerID=40\&md5=1388425e3516b1aee8246321c96d ead7. Scopus

173. HUANG, J., LIN, Q., ZHANG, X., HE, X., XING, X., LIAN, W., ZUO, M. and ZHANG, Q. Electrochemical immunosensor based on polyaniline/poly (acrylic acid) and Au-hybrid graphene nanocomposite for sensitivity enhanced detection of salbutamol. Food Research International. v. 44, n. 1, p. 92-97. 2011. DOI 10.1016/j.foodres.2010.11.006. Scopus

174. PETROVSKI, A., PAUNOVIĆ, P.P., GROZDANOV, A., DIMITROV, A.T., MICKOVA, I., GENTILE, G. and AVELLA, M. Electrochemical polymerization and in situ characterization of PANI in presence of chemically modified graphene. Bulgarian Chemical Communications. v. 52, p. 41-48. 2020. Scopus 175. JIA, Y., MA, D. and WANG, X. Electrochemical preparation and application of PANI/MWNT and PPy/MWNT composite anodes for anaerobic fluidized bed microbial fuel cell. 3 Biotech [online]. v. 10, $\mathrm{n}$. 1. 2020. DOI 10.1007/s13205-019-1950-y. Available from: https://www.scopus.com/inward/record.uri? eid=2-s2.0-85075553243\&doi=10.1007\%2fs13205-019-1950-

$y \&$ partnerlD $=40 \& m d 5=c 5 d 32 b 787 e 421 f 341049 d e 8 f 4618 a b d d$. Scopus

176. LI, Jing, XIE, Huaqing, LI, Yang, LIU, Jie and LI, Zhuxin. Electrochemical properties of graphene nanosheets/polyaniline nanofibers composites as electrode for supercapacitors. Journal of Power Sources. v. 196, n. 24, p. 10775-10781. 2011. DOI https://doi.org/10.1016/j.jpowsour.2011.08.105. 
177. SHAKIR, M.F., KHAN, A.N., KHAN, R., JAVED, S., TARIQ, A., AZEEM, M., RIAZ, A., SHAFQAT, A., CHEEMA, H.M., AKRAM, M.A., AHMAD, I. and JAN, R. EMI shielding properties of polymer blends with inclusion of graphene nano platelets. Results in Physics [online]. v. 14. 2019. DOI 10.1016/j.rinp.2019.102365. Available from: https://www.scopus.com/inward/record.uri?eid=2-s2.085066293606\&doi=10.1016\%2fj.rinp.2019.102365\&partnerlD=40\&md5=4d16fea7a7218c35ee4d85b2418a ce94. Scopus

178. WANG, L., YAO, Q., XIAO, J., ZENG, K., QU, S., SHI, W., WANG, Q. and CHEN, L. Engineered Molecular Chain Ordering in Single-Walled Carbon Nanotubes/Polyaniline Composite Films for High-Performance Organic Thermoelectric Materials. Chemistry - An Asian Journal . v. 11, n. 12, p. 1804-1810. 2016. DOI 10.1002/asia.201600212. Scopus

179. WANG, H., YI, S.-I. and YU, C. Engineering electrical transport at the interface of conjugated carbon structures to improve thermoelectric properties of their composites. Polymer. v. 97, p. 487-495. 2016. DOI 10.1016/j.polymer.2016.05.062. Scopus

180. IM, J.S., KIM, J.G., LEE, S.-H. and LEE, Y.-S. Enhanced adhesion and dispersion of carbon nanotube in PANI/PEO electrospun fibers for shielding effectiveness of electromagnetic interference. Colloids and

Surfaces A: Physicochemical and Engineering Aspects. v. 364, n. 1-3, p. 151-157. 2010. DOI 10.1016/j.colsurfa.2010.05.015. Scopus

181. RAJYALAKSHMI, T., PASHA, A., KHASIM, S., LAKSHMI, M., MURUGENDRAPPA, M.V. and BADI, N. Enhanced Charge Transport and Corrosion Protection Properties of Polyaniline-Carbon Nanotube Composite Coatings on Mild Steel. Journal of Electronic Materials. v. 49, n. 1, p. 341-352. 2020. DOI 10.1007/s11664-019-07783-6. Scopus

182. USMAN, M., PAN, L., ASIF, M., MAHMOOD, Z., KHAN, M.A. and FU, X. Enhanced electrochemical supercapacitor properties with synergistic effect of polyaniline, graphene and Ag $\times$ O. Applied Surface Science. v. 370, p. 297-305. 2016. DOI 10.1016/j.apsusc.2016.02.175. Scopus

183. LI, H., LIU, Y., LI, P., LIU, S., DU, F. and HE, C. Enhanced Thermoelectric Performance of Carbon Nanotubes/Polyaniline Composites by Multiple Interface Engineering. ACS Applied Materials and Interfaces. v. 13, n. 5, p. 6650-6658. 2021. DOI 10.1021/acsami.0c20931. Scopus

184. YAO, Q., CHEN, L., ZHANG, W., LIUFU, S. and CHEN, X. Enhanced thermoelectric performance of singlewalled carbon nanotubes/polyaniline hybrid nanocomposites. ACS Nano. v. 4, n. 4, p. 2445-2451. 2010. DOI 10.1021/nn1002562. Scopus

185. WANG, S., ZHOU, Y., LIU, Y., WANG, L. and GAO, C. Enhanced thermoelectric properties of polyaniline/polypyrrole/carbon nanotube ternary composites by treatment with a secondary dopant using ferric chloride. Journal of Materials Chemistry C. v. 8, n. 2, p. 528-535. 2020. DOI 10.1039/c9tc06300e. Scopus

186. DONG, J.-Q. and SHEN, Q. Enhancement in solubility and conductivity of polyaniline with lignosulfonate modified carbon nanotube. Journal of Polymer Science, Part B: Polymer Physics . v. 47, n. 20, p. 2036-2046. 2009. DOI 10.1002/polb.21802. Scopus 
187. IMRAN, S.M., KIM, Y., SHAO, G.N., HUSSAIN, M., CHOA, Y.-H. and KIM, H.T. Enhancement of electroconductivity of polyaniline/graphene oxide nanocomposites through in situ emulsion polymerization. Journal of Materials Science. v. 49, n. 3, p. 1328-1335. 2014. DOI 10.1007/s10853-013-7816-5. Scopus 188. WANG, S., LIU, F., GAO, C., WAN, T., WANG, L., WANG, L. and WANG, L. Enhancement of the thermoelectric property of nanostructured polyaniline/carbon nanotube composites by introducing pyrrole unit onto polyaniline backbone via a sustainable method. Chemical Engineering Journal. v. 370, p. 322329. 2019. DOI 10.1016/j.cej.2019.03.155. Scopus

189. GU, H., TADAKAMALLA, S., ZHANG, X., HUANG, Y., JIANG, Y., COLORADO, H.A., LUO, Z., WEl, S. and GUO, Z. Epoxy resin nanosuspensions and reinforced nanocomposites from polyaniline stabilized multiwalled carbon nanotubes. Journal of Materials Chemistry C. v. 1, n. 4, p. 729-743. 2013. DOI 10.1039/c2tc00379a. Scopus 190. JASIM, Ashwak, ULLAH, Muhammad Wajid, SHI, Zhijun, LIN, Xiao and YANG, Guang. Fabrication of bacterial cellulose/polyaniline/single-walled carbon nanotubes membrane for potential application as biosensor. Carbohydrate Polymers. v. 163, p. 62-69. 2017. DOI https://doi.org/10.1016/j.carbpol.2017.01.056.

191. FARAJI, Masoud, MOGHADAM, Peyman Najafi and HASANZADEH, Reza. Fabrication of binder-free polyaniline grafted multiwalled carbon nanotube/TiO2 nanotubes/Ti as a novel energy storage electrode for supercapacitor applications. Chemical Engineering Journal. v. 304, p. 841-851. 2016. DOI https://doi.org/10.1016/j.cej.2016.07.034.

192. ZELIKMAN, E., SUCKEVERIENE, R.Y., MECHREZA, G. and NARKIS, M. Fabrication of composite polyaniline/CNT nanofibers using an ultrasonically assisted dynamic inverse emulsion polymerization technique. Polymers for Advanced Technologies. v. 21, n. 2, p. 150-152. 2010. DOI 10.1002/pat.1464. Scopus

193. TAN, H., XIAO, D., NAVIK, R., GOTO, M. and ZHAO, Y. Fabrication of graphene/polyaniline nanofiber multilayer composite for supercapacitor electrodes via layer-by-layer vacuum filtration. Journal of

Materials Science: Materials in Electronics. v. 31, n. 21, p. 18569-18580. 2020. DOI 10.1007/s10854020-04400-9. Scopus

194. WANG, Hongxing, LIU, Dong, DU, Pengcheng and LIU, Peng. Facile deposition of polyaniline on the multi-walled carbon nanotubes/polyvinyl chloride composite films as flexible and robust electrodes for high performance supercapacitors. Electrochimica Acta. v. 289, p. 104-111. 2018. DOI https://doi.org/10.1016/j.electacta.2018.09.031.

195. HE, F.-G., YIN, J.-Y., SHARMA, G., KUMAR, A., STADLER, F.J. and DU, B. Facile fabrication of hierarchical rGO/PANI@PtNi nanocomposite via microwave-assisted treatment for non-enzymatic detection of hydrogen peroxide. Nanomaterials [online]. v. 9, n. 8. 2019. DOI 10.3390/nano9081109. Available from: https://www.scopus.com/inward/record.uri?eid=2-s2.085070672926\&doi=10.3390\%2fnano9081109\&partnerID=40\&md5=c71e3798e110b16ec608ff8303d39103. Scopus 
196. LI, P., ZHAO, Y., LI, H., LIU, S., LIANG, Y., CHENG, X. and HE, C. Facile green strategy for improving thermoelectric performance of carbon nanotube/polyaniline composites by ethanol treatment.

Composites Science and Technology [online]. v. 189. 2020. DOI 10.1016/j.compscitech.2020.108023. Available from: https://www.scopus.com/inward/record.uri?eid=2-s2.0-

85078478605\&doi=10.1016\%2fj.compscitech.2020.108023\&partnerID=40\&md5=fcb66a77bd13d55e86242 003302bedf3. Scopus

197. FENG, L., WU, R., LIU, C., LAN, J., LIN, Y.-H. and YANG, X. Facile Green Vacuum-Assisted Method for Polyaniline/SWCNT Hybrid Films with Enhanced Thermoelectric Performance by Interfacial Morphology Control. ACS Applied Energy Materials. v. 4, n. 4, p. 4081-4089. 2021. DOI 10.1021/acsaem.1c00419. Scopus

198. XIAO, H.-M., ZHANG, W.-D., NA, L., HUANG, G.-W., LIU, Y. and FU, S.-Y. Facile preparation of highly conductive, flexible, and strong carbon nanotube/polyaniline composite films. Journal of Polymer Science, Part A: Polymer Chemistry. v. 53, n. 13, p. 1575-1585. 2015. DOI 10.1002/pola.27588. Scopus

199. HOU, L., ZHANG, W., ZHOU, H. and ZHAI, H.-J. Facile preparation of polyaniline-carbon nanotube hybrid electrodes and dependence of their supercapacitive properties on degree of carboxylation of carbon nanotubes. Journal of Nanoparticle Research [online]. v. 22, n. 1. 2020. DOI 10.1007/s11051-0194737-5. Available from: https://www.scopus.com/inward/record.uri?eid=2-s2.085077509292\&doi=10.1007\%2fs11051-019-4737-

$5 \&$ partner $I D=40 \& m d 5=$ ba6ee1426b624b0c30cc85efd9e22b18. Scopus 200. GUPTA, R., VADODARIYA, N., MAHTO, A., CHAUDHARY, J.P., PARMAR, D.B., SRIVASTAVA, D.N., NATARAJ, S.K. and MEENA, R. Functionalized seaweed-derived graphene/polyaniline nanocomposite as efficient energy storage electrode. Journal of Applied Electrochemistry . v. 48, n. 1, p. 37-48. 2018. DOI 10.1007/s10800-017-1120-z. Scopus

201. ZHU, J., HUO, X., LIU, X. and JU, H. Gold Nanoparticles Deposited Polyaniline-TiO2 Nanotube for Surface Plasmon Resonance Enhanced Photoelectrochemical Biosensing. ACS Applied Materials and Interfaces. v. 8, n. 1, p. 341-349. 2016. DOI 10.1021/acsami.5b08837. Scopus 202. JEON, I.N.-Y., KANG, S.-W., LOON-SENG, T.A.N. and BAEK, J.-B. Grafting of polyaniline onto the surface of 4-aminobenzoylfunctionalized multiwalled carbon nanotube and its electrochemical properties. Journal of Polymer Science, Part A: Polymer Chemistry. v. 48, n. 14, p. 3103-3112. 2010. DOI 10.1002/pola.24091. Scopus 203. IAKOBSON, O.D., GRIBKOVA, O.L., TAMEEV, A.R., NEKRASOV, A.A., SARANIN, D.S. and DI CARLO, A. Graphene nanosheet/polyaniline composite for transparent hole transporting layer. Journal of Industrial and Engineering Chemistry. v. 65, p. 309-317. 2018. DOI 10.1016/j.jiec.2018.04.042. Scopus 204. KARKOOTI, A., RASTGAR, M., NAZEMIFARD, N. and SADRZADEH, M. Graphene-based electroconductive anti-fouling membranes for the treatment of oil sands produced water. Science of the Total Environment [online]. v. 704. 2020. DOI 10.1016/j.scitotenv.2019.135365. Available from: 
https://www.scopus.com/inward/record.uri?eid=2-s2.0-

85075890289\&doi=10.1016\%2fj.scitotenv.2019.135365\&partnerID=40\&md5=ac1501c559edd7549ad9699 49ea83357. Scopus

205. JEONG, G.-H., KIM, S.-J., HAN, E.-M. and PARK, K.H. Graphene/Polyaniline Nanocomposite Multilayer Counter Electrode by Inserted Polyaniline of Dye-Sensitized Solar Cells. Molecular Crystals and Liquid Crystals. v. 620, n. 1, p. 112-116. 2015. DOI 10.1080/15421406.2015.1094888. Scopus 206. FIRDAUS, S.M., ANASYIDA, A.S., ZUBIR, S.A. and MARIATTI, M. Graphene/polyaniline nanocomposites: effect of in-situ polymerization and solvent blending methods with dodecylbenzene sulfonic acid surfactant. Journal of Materials Science: Materials in Electronics. v. 31, n. 18, p. 15805-15821. 2020. DOI 10.1007/s10854-020-04143-7. Scopus

207. ALI, M.K., HESSEIN, A., HASSAN, M.A., GHALI, M., M. SHAALAN, N., NAKAMURA, K. and EL-MONEIM, A.A. Heteroatom-doped reduced graphene oxide/polyaniline nanocomposites with improved n-type thermoelectric performance. Journal of Applied Polymer Science [online] . v. 138, n. 34. 2021. DOI 10.1002/app.50852. Available from: https://www.scopus.com/inward/record.uri?eid=2-s2.0$85104101912 \&$ doi $=10.1002 \% 2$ fapp.50852\&partnerlD=40\&md5=c8044be11f635d6dded4abdbe4ebef5b. Scopus

208. ZHOU, S., ZENG, S., ZHANG, S., QIAO, J., DI, J., CHEN, M., LIU, N. and LI, Q. Hierarchical carbon nanotube hybrid films for high-performance all-solid-state supercapacitors. RSC Advances. v. 7, n. 82, p. 52010-52016. 2017. DOI 10.1039/c7ra10581a. Scopus 209. HSIEH, Y.-Y., ZHANG, Y., ZHANG, L., FANG, Y., KANAKARAAJ, S.N., BAHK, J.-H. and SHANOV, V. High thermoelectric power-factor composites based on flexible three-dimensional graphene and polyaniline. Nanoscale. v. 11, n. 14, p. 6552-6560. 2019. DOI 10.1039/c8nr10537e. Scopus

210. PENG, C., YU, J., CHEN, S. and WANG, L. High-performance supercapacitor based on ultralight and elastic three-dimensional carbon foam/reduced graphene/polyaniline nanocomposites. Chinese Chemical Letters. v. 30, n. 6, p. 1137-1140. 2019. DOI 10.1016/j.cclet.2019.02.007. Scopus 211. PHATTHARASUPAKUN, N., WUTTHIPROM, J., MA, N., SUKTHA, P. and SAWANGPHRUK, M. Highperformance supercapacitors of $\mathrm{N}$-doped graphene aerogel and its nanocomposites with manganese oxide and polyaniline. Journal of the Electrochemical Society. v. 165, n. 7, p. A1430-A1439. 2018. DOI 10.1149/2.0981807jes. Scopus

212. GONG, J., XU, Z., TANG, Z., ZHONG, J. and ZHANG, L. Highly compressible 3-D hierarchical porous carbon nanotube/metal organic framework/polyaniline hybrid sponges supercapacitors. AIP Advances [online]. v. 9, n. 5. 2019. DOI 10.1063/1.5109042. Available from:

https://www.scopus.com/inward/record.uri?eid=2-s2.085066813594\&doi=10.1063\%2f1.5109042\&partnerlD=40\&md5=c83a934f21effc92f1d9642d0e2c2e65. Scopus

213. ZAHED, M.A., BARMAN, S.C., DAS, P.S., SHARIFUZZAMAN, M., YOON, H.S., YOON, S.H. and PARK, J.Y. Highly flexible and conductive poly (3, 4-ethylene dioxythiophene)-poly (styrene sulfonate) anchored 3- 
dimensional porous graphene network-based electrochemical biosensor for glucose and $\mathrm{pH}$ detection in human perspiration. Biosensors and Bioelectronics [online]. v. 160. 2020. DOI 10.1016/j.bios.2020.112220. Available from: https://www.scopus.com/inward/record.uri?eid=2-s2.0$85083699320 \&$ doi $=10.1016 \% 2$ fj. bios.2020.112220\&partnerlD=40\&md5=3a73d4c8ab96e65d7148a42c997 6f884. Scopus

214. OU, X.-H. and XU, X.-C. Highly improved conductivity of polyaniline-carbon nanotubes Composites doped by liquid bromine with a synergistic effect. Polymer Composites. v. 39, p. E1034-E1040. 2018. DOI 10.1002/pc.24448. Scopus

215. MOHAN, V.B., JAYARAMAN, K. and BHATTACHARYYA, D. Hybridization of graphene-reinforced two polymer nanocomposites. International Journal of Smart and Nano Materials . v. 7, n. 3, p. 179-201. 2016. DOI 10.1080/19475411.2016.1237389. Scopus

216. RAHNAMOL, A.M. and GOPALAKRISHNAN, J. Improved dielectric and dynamic mechanical properties of epoxy/polyaniline nanorod/in situ reduced graphene oxide hybrid nanocomposites. Polymer Composites. v. 41, n. 8, p. 2998-3013. 2020. DOI 10.1002/pc.25592. Scopus

217. KHODADADI YAZDI, M. and HASHEMI MOTLAGH, G. Improved Electrical and Thermal Aging Properties of DBSA-Doped PANI Using MWCNT and GO. Journal of Electronic Materials. v. 49, n. 9, p. 5326-5334. 2020. DOI 10.1007/s11664-020-08256-x. Scopus 218. ABAD, B., ALDA, I., DÍAZ-ChAO, P., KAWAKAMI, H., ALMARZA, A., AMANTIA, D., GUTIERREZ, D., AUBOUY, L. and MARTÍN-GONZÁLEZ, M. Improved power factor of polyaniline nanocomposites with exfoliated graphene nanoplatelets (GNPs). Journal of Materials Chemistry A. v. 1, n. 35, p. 1045010457. 2013. DOI 10.1039/c3ta12105d. Scopus

219. SOBHA, A. P. and NARAYANANKUTTY, Sunil K. Improved strain sensing property of functionalised multiwalled carbon nanotube/polyaniline composites in TPU matrix. Sensors and Actuators A: Physical . v. 233, p. 98-107. 2015. DOI https://doi.org/10.1016/j.sna.2015.06.012.

220. PATHAK, Abhishek K., KUMAR, V., SHARMA, Sushant, YOKOZEKI, T. and DHAKATE, S. R. Improved thermomechanical and electrical properties of reduced graphene oxide reinforced polyaniline dodecylbenzenesulfonic acid/divinylbenzene nanocomposites. Journal of Colloid and Interface Science. v. 533, p. 548-560. 2019. DOI https://doi.org/10.1016/j.jcis.2018.08.105.

221. NAKAMATSU, H., ITOH, E. and MIYAIRI, K. Improvement of electrical property in laterally aligned CNT/Polyaniline composite thin film by rubbing technique. Molecular Crystals and Liquid Crystals. v. 472, n. 1, p. 95/[485]-103/[493]. 2007. DOI 10.1080/15421400701545163. Scopus 222. PHAN, T.B., MAI, T.X., NGUYEN, T.D., PHAM, T.T., MAI, T.T.T., NGUYEN, T.V.A. and TRAN, D.L. Improving the electrochemical behavior of sustainable polyaniline titanium dioxide composite by intercalation of carbon nanotubes. Green Processing and Synthesis. v. 5, n. 6, p. 549-556. 2016. DOI 10.1515/gps-2016-0109. Scopus

223. GOTTAM, R., SRINIVASAN, P. and KELOTH, B. Improving the Performance of PANI-SA.TiO2 Supercapacitor Active Electrode Material via Emulsion Polymerization of Aniline with MWCNT. 
ChemistrySelect. v. 5, n. 32, p. 10098-10105. 2020. DOI 10.1002/slct.202002585. Scopus

224. ZAMANI KETEKLAHIJANI, Y., SHAYESTEH ZERAATI, A., SHARIF, F., ROBERTS, E.P.L. and SUNDARARAJ, U. In situ chemical polymerization of conducting polymer nanocomposites: Effect of DNA-functionalized carbon nanotubes and nitrogen-doped graphene as catalytic molecular templates. Chemical Engineering Journal [online]. v. 389. 2020. DOI 10.1016/j.cej.2020.124500. Available from:

https://www.scopus.com/inward/record.uri?eid=2-s2.0$85079887585 \&$ doi $=10.1016 \% 2 f j . c e j .2020 .124500 \& p a r t n e r I D=40 \& m d 5=48405 a 7 a 5557 f b 02 d c b f 97 a 65 d 9 e 7$ 968. Scopus

225. WANG, Y., YU, C., SHENG, M., SONG, S. and DENG, Y. Individual Adjustment of Electrical Conductivity and Thermopower Enabled by Multiple Interfaces in Polyaniline-Based Ternary Hybrid Nanomaterials for High Thermoelectric Performances. Advanced Materials Interfaces [online]. v. 5, n. 10. 2018. DOI 10.1002/admi.201701168. Available from: https://www.scopus.com/inward/record.uri?eid=2-s2.085042528295\&doi=10.1002\%2fadmi.201701168\&partnerID=40\&md5=16485587ebdfb4b9412bfdbf32c95e 1e. Scopus

226. ABUTALIB, M.M. Insights into the structural, optical, thermal, dielectric, and electrical properties of PMMA/PANI loaded with graphene oxide nanoparticles. Physica B: Condensed Matter . v. 552, p. 19-29. 2019. DOI 10.1016/j.physb.2018.09.034. Scopus

227. LI, Hui, LIU, Siqi, LI, Pengcheng, YUAN, Du, ZHOU, Xin, SUN, Jiaotong, LU, Xuehong and HE, Chaobin. Interfacial control and carrier tuning of carbon nanotube/polyaniline composites for high thermoelectric performance. Carbon. v. 136, p. 292-298. 2018. DOl https://doi.org/10.1016/j.carbon.2018.04.083. 228. DETSRI, E. and DUBAS, S.T. Layer-by-layer deposition of cationic and anionic carbon nanotubes into thin films with improved electrical properties. Colloids and Surfaces A: Physicochemical and Engineering Aspects. v. 444, p. 89-94. 2014. DOI 10.1016/j.colsurfa.2013.12.040. Scopus 229. SARKER, A.K. and HONG, J.-D. Layer-by-Layer self-assembled multilayer films composed of graphene/polyaniline bilayers: High-Energy electrode materials for supercapacitors. Langmuir. v. $28, \mathrm{n}$. 34, p. 12637-12646. 2012. DOI 10.1021/la3021589. Scopus

230. GABUNADA, J.C., VINOTHKANNAN, M., KIM, D.H., KIM, A.R. and YOO, D.J. Magnetite Nanorods Stabilized by Polyaniline/Reduced Graphene Oxide as a Sensing Platform for Selective and Sensitive Nonenzymatic Hydrogen Peroxide Detection. Electroanalysis. v. 31, n. 8, p. 1524-1533. 2019. DOI 10.1002/elan.201900134. Scopus

231. MOHAN, V.B., SANTHANA KRISHNAN, S. and BHATTACHARYYA, D. Manufacturing and characterization of novel silicone/natural fabric/graphene-based functional composites for human body motion sensing.

Polymer Composites. v. 42, n. 7, p. 3493-3507. 2021. DOI 10.1002/pc.26074. Scopus

232. SHAKIR, H.M.F., TARIQ, A., AFZAL, A. and ABDUL RASHID, I. Mechanical, thermal and EMI shielding study of electrically conductive polymeric hybrid nano-composites. Journal of Materials Science: Materials in Electronics. v. 30, n. 18, p. 17382-17392. 2019. DOI 10.1007/s10854-019-02088-0. Scopus 233. TARAWNEH, M.A., SARAIREH, S.A., CHEN, R.S., AHMAD, S.H., AL-TARAWNI, M.A.M., AL-TWEISSI, M. and 
YU, L.J. Mechanical, thermal, and conductivity performances of novel thermoplastic natural rubber/graphene nanoplates/polyaniline composites. Journal of Applied Polymer Science [online] . v. 137, n. 28. 2020. DOI 10.1002/app.48873. Available from: https://www.scopus.com/inward/record.uri? eid $=2$-s2.0-

85077148379\&doi=10.1002\%2fapp.48873\&partnerID=40\&md5=5a8225e4le46b63937f461233c46e9d1. Scopus

234. CAO, Hailiang, ZHOU, Xufeng, ZHANG, Yiming, CHEN, Liang and LIU, Zhaoping. Microspherical polyaniline/graphene nanocomposites for high performance supercapacitors. Journal of Power Sources. v. 243, p. 715-720. 2013. DOI https://doi.org/10.1016/j.jpowsour.2013.06.032.

235. LI, Hui, LIANG, Yuan, LIU, Siqi, QIAO, Fen, LI, Pengcheng and HE, Chaobin. Modulating carrier transport for the enhanced thermoelectric performance of carbon nanotubes/polyaniline composites. Organic Electronics. v. 69, p. 62-68. 2019. DOI https://doi.org/10.1016/j.orgel.2019.03.006.

236. TANGUY, N.R., ARJMAND, M. and YAN, N. Nanocomposite of Nitrogen-Doped Graphene/Polyaniline for Enhanced Ammonia Gas Detection. Advanced Materials Interfaces [online]. v. 6, n. 16. 2019. DOI 10.1002/admi.201900552. Available from: https://www.scopus.com/inward/record.uri?eid=2-s2.0$85067383037 \&$ doi $=10.1002 \% 2 \mathrm{fadmi} .201900552 \&$ partnerID $=40 \& \mathrm{md5}=8 \mathrm{cda} 36 \mathrm{c} 10 \mathrm{~cd} 037 \mathrm{de} 992 \mathrm{e} 4095168 \mathrm{~b} 6$ 13f. Scopus

237. HUSSAIN, S.T., ABBAS, F., KAUSAR, A. and KHAN, M.R. New polyaniline/polypyrrole/polythiophene and functionalized multiwalled carbon nanotube-based nanocomposites: Layer-by-layer in situ polymerization. High Performance Polymers. v. 25, n. 1, p. 70-78. 2013. DOI 10.1177/0954008312456048. Scopus 238. LONG, T., MENG, F., XU, B., ZHAO, Y., LIU, W., WEI, X., ZHENG, L. and LIU, J. Nitrogen-doped carbon nanotubes intertwined with porous carbon with enhanced cathode performance in lithium-sulfur batteries. Sustainable Energy and Fuels. v. 4, n. 8, p. 3926-3933. 2020. DOI 10.1039/d0se00583e. Scopus 239. WANG, Y., WU, S., YIN, Q., DU, K., YIN, Q., JIANG, B. and MO, S. Novel Hybrid p- And n-Type Organic Thermoelectric Materials Based on Mussel-Inspired Polydopamine. ACS Applied Materials and Interfaces. v. 13, n. 20, p. 23970-23982. 2021. DOI 10.1021/acsami.1c01457. Scopus 240. ZHAO, Y., MA, J., CHEN, K., ZHANG, C., YAO, C., ZUO, S. and KONG, Y. One-Pot Preparation of Graphene-Based Polyaniline Conductive Nanocomposites for Anticorrosion Coatings. Nano [online]. v. 12, n. 5. 2017. DOI 10.1142/S1793292017500564. Available from: https://www.scopus.com/inward/record.uri? eid $=2$-s2.0$85018841211 \& d o i=10.1142 \% 2 f S 1793292017500564 \&$ partnerlD $=40 \&$ md5 $=2$ b7aced845bfa $70 d a 741 d 2 b 884$ $8 \mathrm{fb} 68 \mathrm{e}$. Scopus

241. CHIN, S.Y., ABDULLAH, T.K. and MARIATTI, M. One-step synthesis of conductive graphene/polyaniline nanocomposites using sodium dodecylbenzenesulfonate: preparation and properties. Journal of

Materials Science: Materials in Electronics. v. 28, n. 24, p. 18418-18428. 2017. DOI 10.1007/s10854017-7788-3. Scopus

242. MERIGA, V., VALLIGATLA, S., SUNDARESAN, S., CAHILL, C., DHANAK, V.R. and CHAKRABORTY, A.K. 
Optical, electrical, and electrochemical properties of graphene based water soluble polyaniline composites. Journal of Applied Polymer Science [online]. v. 132, n. 45. 2015. DOI 10.1002/app.42766. Available from: https://www.scopus.com/inward/record.uri?eid=2-s2.0$84940897614 \&$ doi $=10.1002 \% 2$ fapp $.42766 \&$ partnerlD=40\&md5=d91a406c5df2a09faa7b236e40c4c8d6. Scopus

243. BARUAH, S., KUMAR, S., NAYAK, B. and PUZARI, A. Optoelectronically suitable graphene oxidedecorated titanium oxide/polyaniline hybrid nanocomposites and their enhanced photocatalytic activity with methylene blue and rhodamine B dye. Polymer Bulletin. v. 78, n. 3, p. 1703-1720. 2021. DOI 10.1007/s00289-020-03182-8. Scopus

244. CHO, C., SONG, Y., HSU, J.-H., YU, C., STEVENS, D.L. and GRUNLAN, J.C. Organic thermoelectric thin films with large p-type and n-type power factor. Journal of Materials Science. v. 56, n. 6, p. 4291-4304. 2021. DOI 10.1007/s10853-020-05520-7. Scopus

245. WANG, L., YAO, Q., BI, H., HUANG, F., WANG, Q. and CHEN, L. PANI/graphene nanocomposite films with high thermoelectric properties by enhanced molecular ordering. Journal of Materials Chemistry A. v. 3, n. 13, p. 7086-7092. 2015. DOI 10.1039/c4ta06422d. Scopus

246. NEELGUND, Gururaj M., BLIZNYUK, Valery N. and OKI, Aderemi. Photocatalytic activity and NIR laser response of polyaniline conjugated graphene nanocomposite prepared by a novel acid-less method.

Applied Catalysis B: Environmental. v. 187, p. 357-366. 2016. DOI

https://doi.org/10.1016/j.apcatb.2016.01.009.

247. WANG, G., DING, Y., WANG, F., LI, X. and LI, C. Poly(aniline-2-sulfonic acid) modified multiwalled carbon nanotubes with good aqueous dispersibility. Journal of Colloid and Interface Science . v. 317, n. 1, p. 199-205. 2008. DOI 10.1016/j.jcis.2007.09.033. Scopus

248. LI, Y., YAN, Q., WANG, Y., LI, Y., ZHU, M., CHENG, K., YE, K., ZHU, K., YAN, J., CAO, D., ZHANG, X. and WANG, G. Polyaniline coated 3D crosslinked carbon nanosheets for high-energy-density supercapacitors. Applied Surface Science. v. 493, p. 506-513. 2019. DOI 10.1016/j.apsusc.2019.07.038. Scopus 249. GRINOU, A., YUN, Y.S. and JIN, H.-J. Polyaniline nanofiber-coated polystyrene/graphene oxide coreshell microsphere composites. Macromolecular Research. v. 20, n. 1, p. 84-92. 2012. DOI 10.1007/s13233-012-0002-9. Scopus 250. DUAN, W., RONEN, A., WALKER, S. and JASSBY, D. Polyaniline-Coated Carbon Nanotube Ultrafiltration Membranes: Enhanced Anodic Stability for in Situ Cleaning and Electro-Oxidation Processes. ACS Applied Materials and Interfaces. v. 8, n. 34, p. 22574-22584. 2016. DOI 10.1021/acsami.6b07196. Scopus 251. ZHOU, Xiaoming, LIU, Yang, DU, Chunyu, REN, Yang, MU, Tiansheng, ZUO, Pengjian, YIN, Geping, MA, Yulin, CHENG, Xinqun and GAO, Yunzhi. Polyaniline-encapsulated silicon on three-dimensional carbon nanotubes foam with enhanced electrochemical performance for lithium-ion batteries. Journal of Power Sources. v. 381, p. 156-163. 2018. DOI https://doi.org/10.1016/j.jpowsour.2018.02.009.

252. JEEVANANDA, T., SIDDARAMAIAH, LEE, T.S., LEE, J.H., SAMIR, O.M. and SOMASHEKAR, R. Polyanilinemultiwalled carbon nanotube composites: Characterization by WAXS and TGA. Journal of Applied 
Polymer Science. v. 109, n. 1, p. 200-210. 2008. DOI 10.1002/app.27847. Scopus

253. KIM, J.-W., SIOCHI, E.J., CARPENA-NÚÑEZ, J., WISE, K.E., CONNELL, J.W., LIN, Y. and WINCHESKI, R.A. Polyaniline/carbon nanotube sheet nanocomposites: Fabrication and characterization. ACS Applied Materials and Interfaces. v. 5, n. 17, p. 8597-8606. 2013. DOI 10.1021/am402077d. Scopus 254. GRINOU, A., BAK, H., YUN, Y.S. and JIN, H.-J. Polyaniline/Silver Nanoparticle-Doped Multiwalled Carbon Nanotube Composites. Journal of Dispersion Science and Technology . v. 33, n. 5, p. 750-755. 2012. DOI 10.1080/01932691.2011.567862. Scopus

255. FAN, W., MIAO, Y.-E., ZHANG, L., HUANG, Y. and LIU, T. Porous graphene-carbon nanotube hybrid paper as a flexible nano-scaffold for polyaniline immobilization and application in all-solid-state supercapacitors. RSC Advances. v. 5, n. 39, p. 31064-31073. 2015. DOI 10.1039/c5ra02902c. Scopus 256. MU, B., LIU, P., YU, X., PAN, F., GAO, Z. and LIU, X. Preparation and characterization of conductorinsulator-semiconductor sandwich-structured MWCNT/double-layer polymer hybrid nanocomposites. Synthetic Metals. v. 160, n. 21-22, p. 2329-2335. 2010. DOI 10.1016/j.synthmet.2010.09.007. Scopus 257. TUNG, N.T., VAN KHAI, T., JEON, M., LEE, Y.J., CHUNG, H., BANG, J.-H. and SOHN, D. Preparation and characterization of nanocomposite based on polyaniline and graphene nanosheets. Macromolecular Research. v. 19, n. 2, p. 203-208. 2011. DOI 10.1007/s13233-011-0216-2. Scopus 258. WU, H., LA, M., LI, J., HAN, Y., FENG, Y., PENG, Q. and HAO, C. Preparation and electrochemical properties of MnO 2 /PANI-CNTs composites materials. Composite Interfaces. v. 26, n. 8, p. 659-677. 2019. DOI 10.1080/09276440.2018.1526592. Scopus

259. ZHANG, H., JIANG, T., HE, X., CHEN, T., FAN, L., GAO, M. and LIU, P. Preparation and properties of cellulose nanofibril-graphene nanosheets/polyaniline composite conductive aerogels. BioResources. v. 15, n. 1, p. 1828-1843. 2020. DOI 10.15376/biores.15.1.1828-1843. Scopus

260. ZHANG, Q., WANG, W., LI, J., ZHU, J., WANG, L., ZHU, M. and JIANG, W. Preparation and thermoelectric properties of multi-walled carbon nanotube/polyaniline hybrid nanocomposites. Journal of Materials Chemistry A. v. 1, n. 39, p. 12109-12114. 2013. DOI 10.1039/c3ta12353g. Scopus 261. BANIASADI, Hossein, S.A, Ahmad Ramazani, MASHAYEKHAN, Shohreh and GHADERINEZHAD, Fariba. Preparation of conductive polyaniline/graphene nanocomposites via in situ emulsion polymerization and product characterization. Synthetic Metals. v. 196, p. 199-205. 2014. DOI https://doi.org/10.1016/j.synthmet.2014.08.007. 262. WANG, Q., WANG, Y., MENG, Q., WANG, T., GUO, W., WU, G. and YOU, L. Preparation of high antistatic HDPE/polyaniline encapsulated graphene nanoplatelet composites by solution blending. RSC Advances. v. 7, n. 5, p. 2796-2803. 2017. DOI 10.1039/C6RA26458A. Scopus 263. AMIRABAD, R., RAMAZANI SAADATABADI, A. and SIADATI, M.H. Preparation of polyaniline/graphene coated wearable thermoelectric fabric using ultrasonic-assisted dip-coating method. Materials for Renewable and Sustainable Energy [online]. v. 9, n. 4. 2020. DOI 10.1007/s40243-020-00181-7. Available from: https://www.scopus.com/inward/record.uri?eid=2-s2.085091951020\&doi=10.1007\%2fs40243-020-00181- 
7\&partner ID $=40 \& m d 5=1037 f a 3150 d 5087 a 6 d 53160 a 35 f 6 a 79 c$. Scopus

264. LIU, X., YANG, W., XU, H. and WANG, W. Pulse electropolymerization and thermoelectrical performances of carbon nanotubes/polyaniline composite film. ECS Journal of Solid State Science and Technology. v. 5, n. 5, p. M27-M30. 2016. DOI 10.1149/2.0111605jss. Scopus 265. WANG, Y.-C., ZHU, B.-Y., NI, J.-F., ZHANG, L., WANG, H.-B. and GAO, L.-J. Pyrolyzed PolyanilineGraphene Nanosheets with Enhanced Lithium-Storage Properties: Preparation and Characterization. ChemElectroChem. v. 1, n. 5, p. 951-956. 2014. DOI 10.1002/celc.201300177. Scopus 266. MitRA, M., KULSI, C., ChATTERJEe, K., KARGUPTA, K., GANGULY, S., BANERJEE, D. and GOSWAMI, S. Reduced graphene oxide-polyaniline composites - Synthesis, characterization and optimization for thermoelectric applications. RSC Advances. v. 5, n. 39, p. 31039-31048. 2015. DOI 10.1039/c5ra01794g. Scopus

267. YIN, Q., SHU, R., XING, H., TAN, D., GAN, Y. and XU, G. Rheological Behavior and Electrical Properties of Graphene Oxide/Polyaniline Nanocomposites. Nano [online]. v. 11, n. 2. 2016. DOI

10.1142/S179329201650020X. Available from: https://www.scopus.com/inward/record.uri?eid=2-s2.084959076696\&doi=10.1142\%2fS179329201650020X\&partnerID=40\&md5=0d426db29e89383c5371cbb71 8382721. Scopus 268. XIAO, F., YANG, S., ZHANG, Z., LIU, H., XIAO, J., WAN, L., LUO, J., WANG, S. and LIU, Y. Scalable Synthesis of Freestanding Sandwich-structured Graphene/Polyaniline/Graphene Nanocomposite Paper for Flexible All-Solid-State Supercapacitor. Scientific Reports [online]. v. 5. 2015. DOI 10.1038/srep09359. Available from: https://www.scopus.com/inward/record.uri?eid=2-s2.084925437124\&doi=10.1038\%2fsrep09359\&partnerID=40\&md5=23e806b31f3361ce1bb0ba391599a584. Scopus

269. KUMAR, V., YOKOZEKI, T., GOTO, T., TAKAHASHI, T., SHARMA, S., DHAKATE, S.R. and SINGH, B.P. Scavenging phenomenon and improved electrical and mechanical properties of polyaniline-divinylbenzene composite in presence of MWCNT. International Journal of Mechanics and Materials in Design . $v$. 14, n. 4, p. 697-708. 2018. DOI 10.1007/s10999-017-9397-y. Scopus 270. ZHOU, Zehang, ZHANG, Xinxing, WU, Xiaodong and LU, Canhui. Self-stabilized polyaniline@graphene aqueous colloids for the construction of assembled conductive network in rubber matrix and its chemical sensing application. Composites Science and Technology. v. 125, p. 1-8. 2016. DOI https://doi.org/10.1016/j.compscitech.2016.01.016.

271. KHAN, Mahfoozurrahman, ANWER, Tarique and MOHAMMAD, Faiz. Sensing properties of sulfonated multi-walled carbon nanotube and graphene nanocomposites with polyaniline. Journal of Science:

Advanced Materials and Devices. v. 4, n. 1, p. 132-142. 2019. DOI https://doi.org/10.1016/j.jsamd.2019.02.002.

272. WAN, Yizao, LI, Jin, YANG, Zhiwei, AO, Haiyong, XIONG, Lingling and LUO, Honglin. Simultaneously depositing polyaniline onto bacterial cellulose nanofibers and graphene nanosheets toward electrically conductive nanocomposites. Current Applied Physics. v. 18, n. 8, p. 933-940. 2018. DOI 
https://doi.org/10.1016/j.cap.2018.05.008.

273. WANG, H., YI, S.-I., PU, X. and YU, C. Simultaneously improving electrical conductivity and thermopower of polyaniline composites by utilizing carbon nanotubes as high mobility conduits. ACS Applied Materials and Interfaces. v. 7, n. 18, p. 9589-9597. 2015. DOI 10.1021/acsami.5b01149. Scopus

274. YUN, S. and KIM, J. Sonication time effect on MWNT/PANI-EB composite for hybrid electro-active paper actuator. Synthetic Metals. v. 157, n. 13-15, p. 523-528. 2007. DOI 10.1016/j.synthmet.2007.05.016. Scopus

275. SAHOO, S., BHATTACHARYA, P., HATUI, G., GHOSH, D. and DAS, C.K. Sonochemical synthesis and characterization of amine-modified graphene/conducting polymer nanocomposites. Journal of Applied Polymer Science. v. 128, n. 3, p. 1476-1483. 2013. DOI 10.1002/app.38285. Scopus

276. CHEN, J., WANG, L., GUI, X., LIN, Z., KE, X., HAO, F., LI, Y., JIANG, Y., WU, Y., SHI, X. and CHEN, L. Strong anisotropy in thermoelectric properties of CNT/PANI composites. Carbon. v. 114, p. 1-7. 2017. DOI 10.1016/j.carbon.2016.11.074. Scopus

277. XU, J., YAO, P., JIANG, Z.-Y. and LI, X. Structure and performance of sulfonated polyaniline grafted multi-walled carbon nanotubes composites. Tianjin Daxue Xuebao (Ziran Kexue yu Gongcheng Jishu Ban)/Journal of Tianjin University Science and Technology. v. 44, n. 4, p. 297-302. 2011. Scopus 278. IMRAN, S.M., SALMAN, A., SHAO, G.N., HAIDER, M.S., ABBAS, N., PARK, S., HUSSAIN, M. and KIM, H.T. Study of the electroconductive properties of conductive polymers-graphene/graphene oxide nanocomposites synthesized via in situ emulsion polymerization. Polymer Composites. v. 39, n. 6, p. 2142-2150. 2018. DOI 10.1002/pc.24179. Scopus

279. KHANDELWAL, V., SAHOO, S.K., KUMAR, A. and MANIK, G. Study on the effect of carbon nanotube on the properties of electrically conductive epoxy/polyaniline adhesives. Journal of Materials Science: Materials in Electronics. v. 28, n. 19, p. 14240-14251. 2017. DOI 10.1007/s10854-017-7282-y. Scopus 280. KUZHANDAIVEL, H., MANICKAM, S., BALASINGAM, S.K., FRANKLIN, M.C., KIM, H.-J. and NALLATHAMBI, K.S. Sulfur and nitrogen-doped graphene quantum dots/PANI nanocomposites for supercapacitors. New Journal of Chemistry. v. 45, n. 8, p. 4101-4110. 2021. DOI 10.1039/d1nj00038a. Scopus 281. MANOJ, M., JASNA, M., ANILKUMAR, K. M., ABHILASH, A., JINISHA, B., PRADEEP, V. S. and JAYALEKSHMI, S. Sulfur-polyaniline coated mesoporous carbon composite in combination with carbon nanotubes interlayer as a superior cathode assembly for high capacity lithium-sulfur cells. Applied Surface Science. v. 458, p. 751-761. 2018. DOI https://doi.org/10.1016/j.apsusc.2018.07.113.

282. PARK, J.-S., CHO, G.-B., RYU, H.-S., AHN, J.-H., AHN, H.-J. and KIM, K.-W. Sulphur-carbon composites for Li/S batteries. Materials Technology. v. 28, n. 5, p. 270-275. 2013. DOI

10.1179/175355513X13621548393253. Scopus

283. CHEN, J., GUI, X., WANG, Z., LI, Z., XIANG, R., WANG, K., WU, D., XIA, X., ZHOU, Y., WANG, Q., TANG, Z. and CHEN, L. Superlow thermal conductivity 3D carbon nanotube network for thermoelectric applications. ACS Applied Materials and Interfaces. v. 4, n. 1, p. 81-86. 2012. DOI 10.1021/am201330f. Scopus 
284. MALLAKPOUR, S., ABDOLMALEKI, A., MAHMOUDIAN, M., ENSAFI, A.A. and ABARGHOUI, M.M. Synergetic effect of synthesized sulfonated polyaniline/quaternized graphene and its application as a highperformance supercapacitor electrode. Journal of Materials Science. v. 52, n. 16, p. 9683-9695. 2017. DOI 10.1007/s10853-017-1118-2. Scopus

285. EREN, O., UCAR, N., ONEN, A., KIZILDAG, N. and KARACAN, I. Synergistic effect of polyaniline, nanosilver, and carbon nanotube mixtures on the structure and properties of polyacrylonitrile composite nanofiber. Journal of Composite Materials. v. 50, n. 15, p. 2073-2086. 2016. DOI 10.1177/0021998315601891. Scopus

286. BHANDARI, S. and KHASTGIR, D. Synergistic effect of simultaneous dual doping in solvent-free mechanochemical synthesis of polyaniline supercapacitor comparable to the composites with multiwalled carbon nanotube. Polymer. v. 81, p. 62-69. 2015. DOI 10.1016/j.polymer.2015.10.015. Scopus 287. LIU, T., LIU, Y., YAN, X., FAN, Y., WANG, P., CAI, Q. and ZHANG, J. Synthesis and characterization of CTAB-intercalated graphene/polyaniline nanocomposites via in situ oxidative polymerization. Polymer Composites. v. 36, n. 10, p. 1767-1774. 2015. DOI 10.1002/pc.22838. Scopus

288. LIN, Y.-W. and WU, T.-M. Synthesis and characterization of externally doped sulfonated polyaniline/multi-walled carbon nanotube composites. Composites Science and Technology. v. 69, n. 15-16, p. 2559-2565. 2009. DOI 10.1016/j.compscitech.2009.07.013. Scopus 289. KUMAR, A., KUMAR, V., KUMAR, M. and AWASTHI, K. Synthesis and characterization of hybrid PANI/MWCNT nanocomposites for EMI applications. Polymer Composites. v. 39, n. 11, p. 3858-3868. 2018. DOI 10.1002/pc.24418. Scopus

290. JEON, I.-Y., LOON-SENG, T.A.N. and BAEK, J.-B. Synthesis and electrical properties of polyaniline/polyaniline grafted multiwalled carbon nanotube mixture via in situ static interfacial polymerization. Journal of Polymer Science, Part A: Polymer Chemistry . v. 48, n. 9, p. 1962-1972. 2010. DOI 10.1002/pola.23963. Scopus 291. KIM, D.K., OH, K.W. and KIM, S.H. Synthesis of polyaniline/multiwall carbon nanotube composite via inverse emulsion polymerization. Journal of Polymer Science, Part B: Polymer Physics . v. 46, n. 20, p. 2255-2266. 2008. DOI 10.1002/polb.21557. Scopus 292. LUO, Jing, JIANG, Sisi, LIU, Ren, ZHANG, Yongjie and LIU, Xiaoya. Synthesis of water dispersible polyaniline/poly(styrenesulfonic acid) modified graphene composite and its electrochemical properties. Electrochimica Acta. v. 96, p. 103-109. 2013. DOI https://doi.org/10.1016/j.electacta.2013.02.072. 293. RAJYALAKSHMI, T., PASHA, A., KHASIM, S., LAKSHMI, M. and IMRAN, M. Synthesis, characterization and Hall-effect studies of highly conductive polyaniline/graphene nanocomposites. SN Applied Sciences [online]. v. 2, n. 4. 2020. DOI 10.1007/s42452-020-2349-4. Available from:

https://www.scopus.com/inward/record.uri?eid=2-s2.0-85100663872\&doi=10.1007\%2fs42452-020-23494\&partnerID $=40 \& m d 5=815 b 63 d c f 7 a c 3 e 84$ eef8aaf2eebadbc3. Scopus 294. KHODADADI YAZDI, M. and HASHEMI MOTLAGH, G. Synthesis, characterization, and thermal aging behavior of $\mathrm{HCl}$-doped polyaniline/TRGO nanocomposites. Journal of Applied Polymer Science 
[online]. v. 134, n. 17. 2017. DOI 10.1002/app.44635. Available from:

https://www.scopus.com/inward/record.uri?eid=2-s2.0-

85010379960\&doi=10.1002\%2fapp.44635\&partnerlD=40\&md5=0033ae60ba42e29b3c5220897333a43a. Scopus

295. XIANG, Jinglei and DRZAL, Lawrence T. Templated growth of polyaniline on exfoliated graphene nanoplatelets (GNP) and its thermoelectric properties. Polymer. v. 53, n. 19, p. 4202-4210. 2012. DOI https://doi.org/10.1016/j.polymer.2012.07.029.

296. CHEN, X., LIU, J., QIAN, K. and WANG, J. Ternary composites of Ni-polyaniline-graphene as counter electrodes for dye-sensitized solar cells. RSC Advances. v. 8, n. 20, p. 10948-10953. 2018. DOI 10.1039/c8ra00934a. Scopus

297. DING, K., BU, Y., LIU, Q., LI, T., MENG, K. and WANG, Y. Ternary-layered nitrogen-doped graphene/sulfur/ polyaniline nanoarchitecture for the high-performance of lithium-sulfur batteries. Journal of Materials Chemistry A. v. 3, n. 15, p. 8022-8027. 2015. DOI 10.1039/c5ta01195g. Scopus 298. SÁNCHEZ, J.A.L., DíEZ-PASCUAL, A.M., CAPILLA, R.P. and DÍAZ, P.G. The effect of hexamethylene diisocyanate-modified graphene oxide as a nanofiller material on the properties of conductive polyaniline.

Polymers [online]. v. 11, n. 6. 2019. DOI 10.3390/polym11061032. Available from:

https://www.scopus.com/inward/record.uri?eid=2-s2.0-

$85067338841 \&$ doi $=10.3390 \% 2$ fpolym11061032\&partnerID=40\&md5=46cd6053581131ef4960a2b4f9fba90

3. Scopus

299. CHENG, Xiuyan, YOKOZEKI, Tomohiro, WU, Lixin, KOYANAGI, Jun, WANG, Haopeng and SUN, Qingfu. The enhancement effect of carbon-based nano-fillers/polyaniline hybrids on the through-thickness electric conductivity of carbon fiber reinforced polymer. Composites Part A: Applied Science and

Manufacturing. v. 105, p. 281-290. 2018. DOI https://doi.org/10.1016/j.compositesa.2017.12.002.

300. LAfUENTE, E., CAllejAS, M. A., SAINZ, R., BENITO, A. M., MASER, W. K., SANJUÁN, M. L., SAUREL, D., TERESA, J. M. de and MARTÍNEZ, M. T. The influence of single-walled carbon nanotube functionalization on the electronic properties of their polyaniline composites. Carbon. v. 46, n. 14, p. 1909-1917. 2008. DOI https://doi.org/10.1016/j.carbon.2008.07.039.

301. ANWER, T. and MOHAMMAD, F. Thermal stability of electrical properties and amine vapour sensitivity of in-situ prepared polyaniline/graphene nanocomposites assisted by sodium dodecyl sulfate micelles.

Polymers and Polymer Composites. v. 23, n. 4, p. 261-270. 2015. DOI 10.1177/096739111502300407. Scopus

302. LIU, J. and YU, H.-Q. Thermoelectric enhancement in polyaniline composites with polypyrrolefunctionalized multiwall carbon nanotubes. Journal of Electronic Materials. v. 43, n. 4, p. 1181-1187. 2014. DOI 10.1007/s11664-013-2958-4. Scopus

303. ZHANG, K., DAVIS, M., QIU, J., HOPE-WEEKS, L. and WANG, S. Thermoelectric properties of porous multi-walled carbon nanotube/polyaniline core/shell nanocomposites. Nanotechnology [online]. v. 23, n. 38. 2012. DOI 10.1088/0957-4484/23/38/385701. Available from: 
https://www.scopus.com/inward/record.uri?eid=2-s2.0-84866110473\&doi=10.1088\%2f09574484\%2f23\%2f38\%2f385701\&partnerID=40\&md5=253c7750d72bef151c4331a034b5d5df. Scopus 304. YAKUPHANOGLU, F. and ŞENKAL, B.F. Thermoelectrical and optical properties of double wall carbon nanotubes: Polyaniline containing boron n-type organic semiconductors. Polymers for Advanced Technologies. v. 19, n. 7, p. 905-908. 2008. DOI 10.1002/pat.1057. Scopus 305. FARAJI, M. Three-dimensional architectures of graphene oxide-polyaniline nanocomposites synthesized by the pulse reverse electrodeposition technique for supercapacitor applications. Ionics. v. 23, n. 2, p. 461-469. 2017. DOI 10.1007/s11581-016-1873-0. Scopus

306. DESHPANDE, M.D. and KONDAWAR, S.B. Transport properties of multi-walled carbon nanotubes based conducting polythiophene / polyaniline nanocomposites. Advanced Materials Letters. v. 7, n. 10, p. 844-850. 2016. DOI 10.5185/amlett.2016.6193. Scopus

307. KYOTANI, M., GOTO, H., SUDA, K., NAGAI, T., MATSUI, Y. and AKAGI, K. Tubular-shaped nanocarbons prepared from polyaniline synthesized by a self-assembly process and their electrical conductivity. Journal of Nanoscience and Nanotechnology. v. 8, n. 4, p. 1999-2004. 2008. DOI 10.1166/jnn.2008.041. Scopus

308. FISHER, R. A. Statistical Methods for Research Workers. In : KOTZ, Samuel and JOHNSON, Norman L. (eds.), Breakthroughs in Statistics: Methodology and Distribution [online]. Springer : New York, NY, 1992. p. 66-70. Springer Series in Statistics. Accessed 18 August 2021. ISBN 978-1-4612-4380-9. Available from: https://doi.org/10.1007/978-1-4612-4380-9_6.

309. FIELD, A. P. Meta-analysis of correlation coefficients: a Monte Carlo comparison of fixed- and randomeffects methods. Psychological Methods. v. 6, n. 2, p. 161-180. 2001. DOI 10.1037/1082-989x.6.2.161. 310. NETHERLANDS, Wolfgang from. Does transformation of $r$ into Fisher $z$ benefit a meta-analysis? [online]. Available from: https://stats.stackexchange.com/q/26534.

311. JONATHON LOVE and W. KYLE HAMILTON. MAJOR code [online]. Available from: https://github.com/kylehamilton/MAJOR/commit/42cec9347aca7bfc200c650f4551ac9743623c9b. 312. ROSENTHAL, Robert. Meta-analysis: A review. Psychosomatic Medicine. v. 53, n. 3, p. 247-271. 1991. DOI 10.1097/00006842-199105000-00001.

313. RENZO, Gian Carlo Di (ed.). Essential Writing, Communication and Narrative Skills for Medical Scientists Before and After the COVID Era [online]. Springer International Publishing, 2022. Accessed 25 August 2021. ISBN 978-3-030-84953-5. Available from: https://www.springer.com/gp/book/9783030849535.

314. KESTENBAUM, Bryan. Epidemiology and Biostatistics: An Introduction to Clinical Research [online]. 2. Springer International Publishing, 2019. Accessed 25 August 2021. ISBN 978-3-319-96642-7. Available from: https://www.springer.com/gp/book/9783319966427. 